\title{
The Relationship Between Levels of Stress and Academic Performance Among University of Nairobi Students
}

\author{
Josiah W.B Oketch-Oboth \\ Department of Psychology \\ University of Nairobi Kenya \\ E-mail: oboth_oketch@uonbi,ac.ke \\ Luke Odiemo Okunya (Corresponding author) \\ Department of Psychology \\ University of Nairobi Kenya \\ E-mail: lukke7@gmail.com
}

Received: August 24, 2018 Accepted: October 9, 2018 Published: October 31, 2018

doi:10.5296/ijld.v8i4.13840 URL: https://doi.org/10.5296/ijld.v8i4.13840

\begin{abstract}
The study investigated the relationship between stress and academic performance among government-sponsored undergraduate students from the University of Nairobi in Kenya. The mediating roles of the students' age, gender, locus of control, level and course of study in the relationship between stress and academic performance were also examined. The sample consisted of 319 male and 265 female students selected using stratified random sampling techniques, from all the six colleges of the university. The study was carried using a cross-sectional survey design involving levels one to five of the academic programs. Data was collected using questionnaires that measured stress and locus of control. Academic performance was assessed from the students' academic transcripts. Both descriptive and inferential statistics were used for data analyses. Two-way and three-way chi- square statistics were used to test the statistical significance of the hypothesis.. The analyses were done using the Statistical Package for Social Sciences (SPSS) computer program. Regression analysis was conducted to find out how the confounding variables contributed to the relationship between stress and academic performance. Results showed that most of the students $(64.4 \%)$
\end{abstract}


reported that they experienced between moderate to high levels of stress while just over a third (35.6\%) reported low stress levels. The relationship between stress and academic performance was statistically significant $\left(\chi^{2}=9.49, \mathrm{~N}=584, \mathrm{df}=4, \mathrm{p}=0.048\right)$. The relationship between stress level and academic performance was significant within 19 to 22 years, 23 to 26 years, males, females, College of Humanities and Social Sciences, College of Agriculture and Veterinary Sciences, levels one and four of study, internal locus of control, and external locus of control. Regression analysis showed that the higher the stress level, the poorer is the academic performance. However, only course/college appears to have statistically significant effect on the relationship between stress and academic performance. The cofounding effect on the stress and academic performance is complex and needs further investigation. The findings indicate the need for relevant authorities to institute programs that will lower the experience and effects of stress among university students. Further research is recommended to investigate the areas where the results were not significant.

Keywords: Academic performance, levels of stress, university students

\section{Background to the Study}

The number of students enrolling in Kenyan public universities has increased tremendously in the last decade (Ng'ang'a, 2016; Njoroge, Wangari, \& Gichure, 2016). The rapid increase in student enrolment has, however, taken place during the period of poor economic performance and when the country is implementing cost-sharing policies (Ngolovoi, 2008; Marcucci, Johnstone, \& Ngolovoi, 2008). Consequently, difficult learning environments in the public universities have been reported (Gudo, Olel, \& Oanda, 2011).

The challenging learning situation has led to a number of negative consequences. Significant dropout rates have been recorded among university students (Njoroge, Wangari, \& Gichure, 2016). It has also been observed that suicidal tendencies have increased (Wanyoike, 2015). There is no actual data because most cases of suicide may go unreported. A significant level of alcohol and drug abuse has also been reported among students in Kenyan universities. For example, Njare (2013) reported a prevalent rate of $63.2 \%$ of alcohol abuse among a sample of 446 students from the University of Nairobi. Similar reports of alcohol abuse in Kenyan universities have recently been reported by a number of studies (Ndegwa, Munene, \& Oladipo, 2017). From the global perspective it has been observed that alcohol and drug abuse is more prevalent among university students than the general population (Tse, 2011; Karama, Kypri, \& Salamoune, 2007).

The challenges that university students face may translate into stress (Arnett, 2010). Stress has been defined from several theoretical perspectives. For example, Hans Selye $(1956,1976)$ proposed the response theory of stress where stress is defined as a physiological response of the body to any demand placed upon it. Lazarus \& Folkman (1984) proposed a cognitive theory in which they defined stress as a cognitive process that involves the perception of stressors in relationship to the coping resources available for the individual to use in the management of stress. Melgosa (2004) incorporated Selye's (1976) and Lazarus \& Folkman's (1984) proposals and defined stress as physiological and psychosocial responses by individuals to stressors that tax their coping abilities. 
For many university students, therefore, university education represents a time of change and new experiences that could lead to serious cognitive and psychosocial challenges (Kagan \& Baird, 2004). University students have to operate in a complex mix of physical, psychosocial and socio-cultural environments with different degrees of challenges (L. A. Bressler \& M. E. Bressler, 2007; Khan, Saleem \& Shahid, 2012; O. H. Ezeh, C. Z. Ezeh, \& Okey, 2016). This situation may be exacerbated because university undergraduate students are young, relatively immature and dependent in the way they relate with other people (Ying Shu, Ming \& Farn, 2009; Frank \& Karyn, 2005).Besides challenges emanating from the internal situation in the university, students also face challenges from outside the university. For instance Kenyan university students reported that they are exposed to potential stressors arising from political and ethnic conflicts in the country (Munene, 2016).

The prevalence of stress-related behaviors among university students may indicate that conditions in the universities present students with stressors which ultimately have the potential to cause stress. This tends to generate negative physical, cognitive and psychosocial outcomes (Rafidah, Azizah, Norzaid, Chang, Salwani, \& Noraini, 2009).

On the one hand it has been argued that stressful conditions in the university are likely to lead to deterioration in academic performance as characterized by low grades and inability to complete class assignments (Smith \& Renk, 2007; Turner, Bartlet, Andiappan, \& Cabot, 2015). On the other hand, there are studies which have failed to confirm the negative relationship between stress and academic performance (Awofodu \& Emi, 2011; Jacob \& Einstein, 2016).

The inconsistency in the relationship between stress and academic performance seems to indicate that this relationship may be mediated by intrinsic and extrinsic stress risk factors (L. A. Bressler \& M. E. Bressler, 2007; Khan, Saleem, \& Shahid, 2012; Thawabieh \& Qaisy, 2012). The intrinsic factors include age (Monteiro, Bolagun, \& Oratile, 2014), gender (Chen, Wong, Ran \& Gilson, 2009; Dughters, Gorka, Matuslewicz \& Anderson, 2013).) and locus of control (Sarrasin, Mayor \& Faniko, 2014; Lecic-Tosevski, Vukovic \& Stepanovic (2011). The extrinsic factors may include level of study (Alzahem, Van der Molen, \& De Boer, 2013), course of study (Nakalema \& Senyonga, 2013; Gokul \& Jayalakshmi, 2016) among others.

The extrinsic factors such as level of study and type of course may constitute stress risk factors because they are characterized by stressors such as academic workload, course assignments and examinations, crowded lecture halls and student hostels, inadequate learning facilities and preparing for examinations (Awofode \& Emi, 2011). The intrinsic factors may affect stress experience because of their association with stress mediating factors. For instance, women tend to benefit more than men from the release of stress hormones (Daughters, Gorka, Matuslewics \& Anderson, 2013) and the buffer effect of social support (Scott, 2009). The age factor in stress has been attributed to the coping strategies used. Older students tend to use more problem-focused and cognitive restructuring coping strategies than their younger colleagues who use emotion-focused coping (Heinman, 2004; Monteiro, Balogun \& Oratile, 2014). Locus of control of control seems to play a mediating role in stress experience because of its effect in the coping process (Khan, Saleem \& Shahid, 2012) and 
self-esteem (Sagone \& De Caroli, 2014)

Unfortunately, few studies have included all levels of study and this has undermined the comparative analysis of the effects of course levels on stress (Alzahem, Van der Molen, \& De Boer, 2013). Without providing any scientific justification, such studies have largely focused not only on single disciplines but on science-based ones with the assumption that these disciplines have more stressors than the humanities and social sciences (Gade, Chan \& Gupta, 2014; Heckman, Lim, \& Montelto, 2014; Jacob, \& Einstein, 2016; Harris, Millichamp, \& Thomson, 2015).

Moreover, researchers have studied student stress from different theoretical perspectives, using samples from a variety of different backgrounds (Eisenberg, Hunt, \& Spear, 2013; Banu, Deb, Vardhan, \& Rao, 2015). The study settings are therefore diverse with their own unique and socio-cultural characteristics (Ibrahim, Kelly, Adams, \& Glazebrook, 2013). From the cognitive perspective, therefore, the socio cultural diversity which characterizes past studies implies that findings of a study in one setting may not be representative of other settings that comprise populations with different socio-cultural backgrounds (Jan \& Popescu, 2014). This may make the findings from such studies not be generalizable because peoples cognitions are influenced by their socio-cultural backgrounds (Sheppard, 2014; Thomson, Kirby \& Smith, 2016); Posner \& Rothbart, 2017). The implication is that findings from stress researches done among university students in Europe, Asia or the United States may not represent the stress experience of students in Kenyan universities.

\subsection{The Purpose of the Study}

The purpose of this study was to investigate the relationship between the students' stress level and academic performance

\section{Methodology}

\subsection{Research Design}

The study used a cross-sectional survey method with stress level as independent variable and academic performance as dependent variable. Age, gender, locus of control, the courses in which they were registered and the levels of study were treated as confounding variables in the relationship between stress and academic performance.

\subsection{The Sample and Sampling Procedure}

The sample consisted of 319(54.62\%) male and 265(45.38\%) female students aged between 19 to 30 years selected using stratified random sampling procedures. The students were distributed according to the levels of study as follows: $80(13.7 \%)$ from level one, $212(36.3 \%)$ from level two, 191(32.7\%) from level three, 83(14.2\%) from level four and 18(3.1\%) from level five. The sample was made up of government- sponsored undergraduate students registered in the following academic programs: 187(32.0\%) from Humanities and Social Sciences, 94(16.1\%) from Education, 100(17.1\%) from Biological and Physical Sciences, 74(12.7\%) from Medical/Health Sciences, 58(9.9\%) from Agriculture and Veterinary Sciences, 71(12.2\%) from Architecture and Engineering The majority of the students were 
residents in the students' halls of residence, sharing university facilities for the time they were in session.

\subsection{Research Instruments}

All the research instruments had Part A which sought the participants' biographical data on age, gender, level and course of study. The following research instruments were used to collect data:

1) A 50-item likert-type 5-point Stress and Coping Strategies Questionnaire was developed and piloted by the researcher. In addition, the Questionnaire had two open-ended items which did not restrict the respondents on the details of their responses

2) Locus of Control was measured by the Locus of Control Questionnaire adapted from Rotter's (1990) Locus of Control Scale. It consists of 23 pairs of items measuring either internal or external locus of control. In addition, it has six pairs of items that do not measure locus of control but act as fillers to help disguise the dimensions of the personality being measured. Although this research tool is standardized it was piloted to customize it to the Kenyan population.

3) Academic performance was assessed using the grades derived from the students' academic transcripts for the two semesters preceding data collection. It was assumed that the performance in the two semesters may have been influenced by the conditions that the students experienced at that time which included the time when data was collected.

\subsection{Validity and Reliability of the Research Instruments}

The researcher ensured content validity of the research instruments by including relevant items for each of the instruments used in the study. The questionnaires and interview schedules were reviewed by two members of the department who teach courses in stress management to establish their face and content validity. The Cronbach's coefficient alpha for the research instruments was 0.920 for the Students Stress and Coping Questionnaire and 0.84 for Locus of Control Questionnaire

\subsection{Data Collection Procedure}

Data was collected by two research assistants trained in research methodology course The choice of research assistants from the college where data were collected was to facilitate rapport with the respondents from their respective colleges. Each research assistant distributed questionnaires to the respondents in the colleges where they were studying.

The research assistants introduced themselves to the respondents and explained the nature of the study and why it was important for the respondents to participate by filling the questionnaires.

The respondents were assured of confidentiality and requested to fill and return the questionnaires to the research assistants within two days. The questionnaires were then 
returned to the researchers as soon as they were received by the research assistants. The researchers scrutinized all the questionnaires when returned to ensure that proper data collection took place. Questionnaires that were not filled properly were not included in the data analysis. The students were requested to provide copies of their academic transcripts for the two semesters. They were assured of confidentiality in handling their academic documents to encourage them cooperate in the release of the documents.

\subsection{Data Analysis}

With regards to the stress questionnaire, respondents were to choose from each item one of the following options: 1=Not stressful at all, 2= Slightly stressful, 3=Stressful, 4=Very stressful and 5=Extremely stressful. The score for each respondent ranged from 50 (Not stressful at all) to 250 (Extremely stressful).. The stress level was divided into three categories as follows: low stress level (50 -125), moderate stress level (126 - 190) and high stress level (191-250).

For each of the 23 pairs of items on locus of control, internal locus of control was scored 1 while external locus of control was scored 2. The score for each respondent on the locus of control instrument therefore ranged from 23 to 46 on the internal-external locus of control continuum

Academic performance was graded as follows: $70 \%$ - 100\% (A), 60\% - 69\% (B), 50\% $-59 \%$ (C), 40\% - 49\% (D) and below 40\% (E). However, for purposes of this study the grades were coded as follows: $\mathrm{A}=5, \mathrm{~B}=4, \mathrm{C}=3, \mathrm{D}=2, \mathrm{E}=1$. Each students' performance therefore ranged from an aggregate score of 1 to 5 .The codes were then divided into three categories as follows: $\mathrm{A}($ Good performance $)=4-5$ points, $\mathrm{B}$ (Moderate performance $)=3$ points and $\mathrm{C}$ (Poor performance) between 1- 2 points

Data was analyzed using SSPS 16 program. Descriptive analyses using frequencies and percentages were conducted to assess the levels and causes of stress. A two-way and three-way chi-square statistics was conducted to test the null hypothesis. Regression analysis to find how the confounding variables contributed to the relationship between stress and academic performance was done using STATA Version 14.0.

\section{Results}

\subsection{Levels of Stress Among Students}

The results show that 208(35.6\%) students had low stress levels, 160(27.6\%) students had moderate stress levels, and 216(37.0\%) students had high stress levels, Among male students, $100(31.3 \%)$ students had low stress levels, 95(29.8\%) students had moderate stress levels while 124(38.9\%) students reported high stress levels. Among female students 108(40.8\%) experienced low stress levels, 65(24.5\%) students had moderate stress level while $92(34,7 \%)$ reported high stress level.

\subsection{Causes of Stress among the Students}

Table 1 and Figure 1 show the most common causes of stress reported by the students. 


\section{Macrothink}

Table 1. Causes of Stress Reported by the Respondents

\begin{tabular}{lllllll}
\hline Causes & Males & $\begin{array}{l}\text { Males } \\
\text { Percentage }\end{array}$ & Females & $\begin{array}{l}\text { Females } \\
\text { percentage }\end{array}$ & Total & $\begin{array}{l}\text { Total } \\
\text { Percentage }\end{array}$ \\
\hline High cost of living & 280 & 87.8 & 160 & 60.4 & 440 & 75.3 \\
Issues with room mates & 245 & 76.8 & 200 & 75.5 & 445 & 76.2 \\
Cost of tuition & 241 & 75.5 & 190 & 71.7 & 431 & 73.8 \\
Dirty halls of residence & 236 & 74.0 & 210 & 79.3 & 446 & 76.4 \\
Fear of failing & 224 & 70.2 & 110 & 41.5 & 334 & 57.2 \\
Course is too demanding & 211 & 66.1 & 206 & 77.7 & 417 & 71.4 \\
No job prospects & 150 & 47.0 & 200 & 75.5 & 350 & 59.9 \\
Relationship issues & 111 & 34.8 & 180 & 67.9 & 291 & 49.8 \\
Ethnic conflicts & 106 & 33.2 & 51 & 19.3 & 157 & 26.9 \\
Uncooperative lecturers & 105 & 32.9 & 100 & 37.7 & 205 & 35.1 \\
Finding accommodation & 101 & 31.7 & 60 & 22.6 & 161 & 27.6 \\
Lack of reading materials & 76 & 23.8 & 60 & 22.6 & 136 & 23.3 \\
Security & 73 & 22.9 & 41 & 15.5 & 114 & 19.5 \\
Poor facilities & 70 & 21.9 & 21 & 7.9 & 91 & 15.6 \\
Poor health services & 60 & 18.8 & 60 & 22.6 & 120 & 20.6 \\
Fear of STI & 40 & 12.6 & 41 & 15.5 & 81 & 13.9 \\
Demand for sex by lecturers & 20 & 6.3 & 150 & 56.6 & 170 & 29.1 \\
Drugs & 20 & 6.3 & 6 & 2.3 & 26 & 4.5 \\
Peer pressure & 19 & 6.0 & 50 & 18.9 & 69 & 11.8 \\
Noise in hostels & 10 & 3.1 & 21 & 7.9 & 31 & 5.3 \\
\hline
\end{tabular}

The most reported causes of stress for all students are dirty halls of residence (76.4\%), issues with roommates $(76.2 \%)$, high cost of living $(75.3 \%)$, cost of tuition $(73.8 \%)$, the course is too demanding $(71.2 \%)$, no job prospects $(59.9 \%)$, fear of failing $(57.2 \%)$, relationship issues (49.8\%), uncooperative lecturers $(35.1 \%)$, demand for sex from lecturers $(29.1 \%)$, finding accommodation $(27.6 \%)$, ethnic conflicts $(26.9 \%)$, lack of reading materials $(23.3 \%)$, poor health services $(20.6 \%)$ and security (19.5\%). socioeconomic and socio-cultural environments in which these students live and study. 


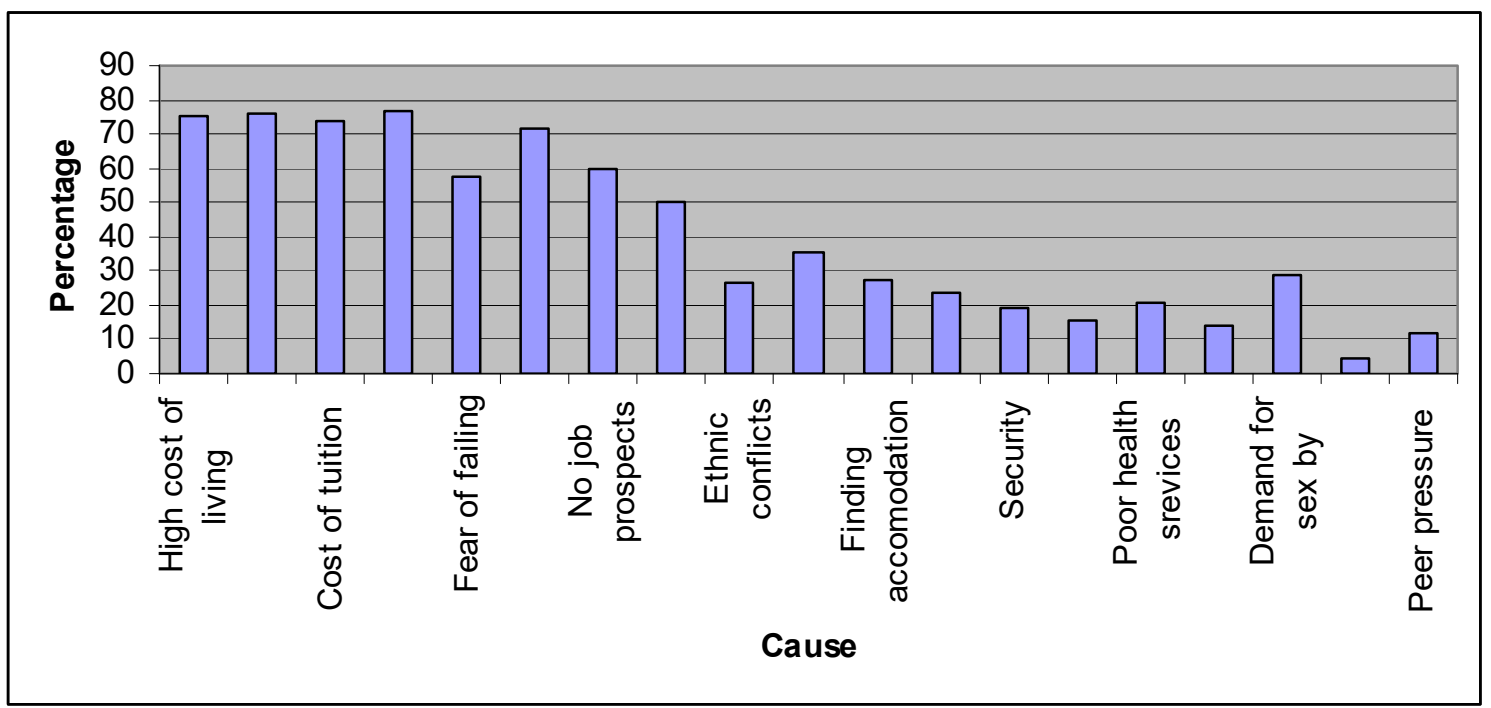

Figure 1. Causes of Stress Reported by all the Students

The pattern, however, changes when male and female students are treated separately. Figure 2 presents causes of stress reported by male students. The most common sources of stress are high cost of living $(87.8 \%)$, issues with roommates $(76.8 \%)$, cost of tuition $(75.5 \%)$, dirty halls of residence $(74.0 \%)$, fear of failing $(70.2 \%)$, course is too demanding $(66.1 \%)$, no job prospects $(47.0 \%)$, relationship issues $(34.8(\%)$, ethnic conflicts $(33.2 \%)$, uncooperative lecturers (32.9\%), finding accommodation (31.7\%), lack of reading materials $(23.8 \%)$, security $(22.9 \%)$ and poor facilities $(21.9 \%)$.

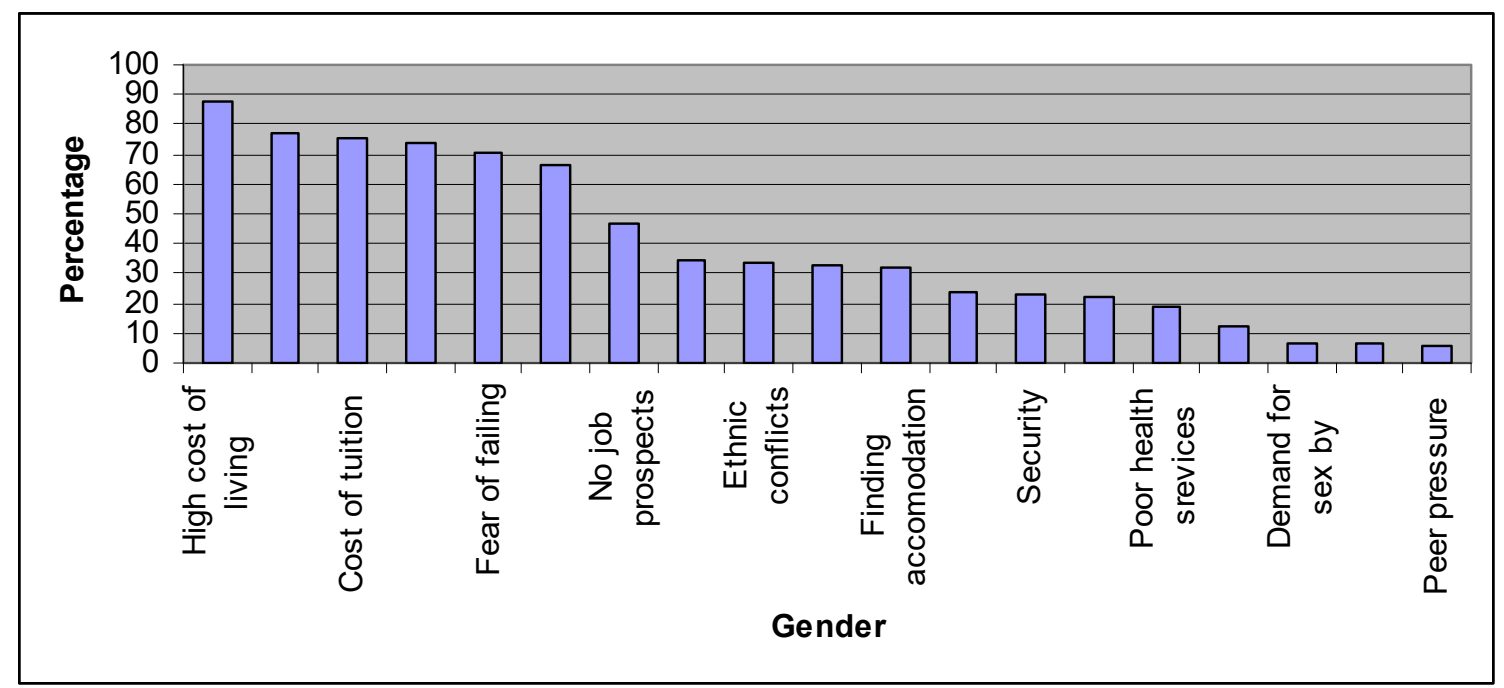

Figure 2. Causes of Stress Reported by Male Respondents

Among female students, the main causes of stress were dirty halls of residence $(79.3 \%)$, 


\section{Macrothink}

International Journal of Learning and Development

ISSN 2164-4063 2018, Vol. 8, No. 4

course is too demanding $(77.7 \%)$, issues with roommates $(75.5 \%)$, no job prospects $(75.5 \%)$, cost of tuition (71.7\%), relationship issues $(67.9 \%)$, high cost of living $(60.4 \%)$, demand for sex by lecturers $(50.6 \%)$, fear of failing $(41.5 \%)$, uncooperative lecturers $(37.7 \%)$, finding accommodation $(22.6 \%)$, lack of reading materials $(22.6 \%)$, poor health services and ethnic conflicts $(19.3 \%)$.

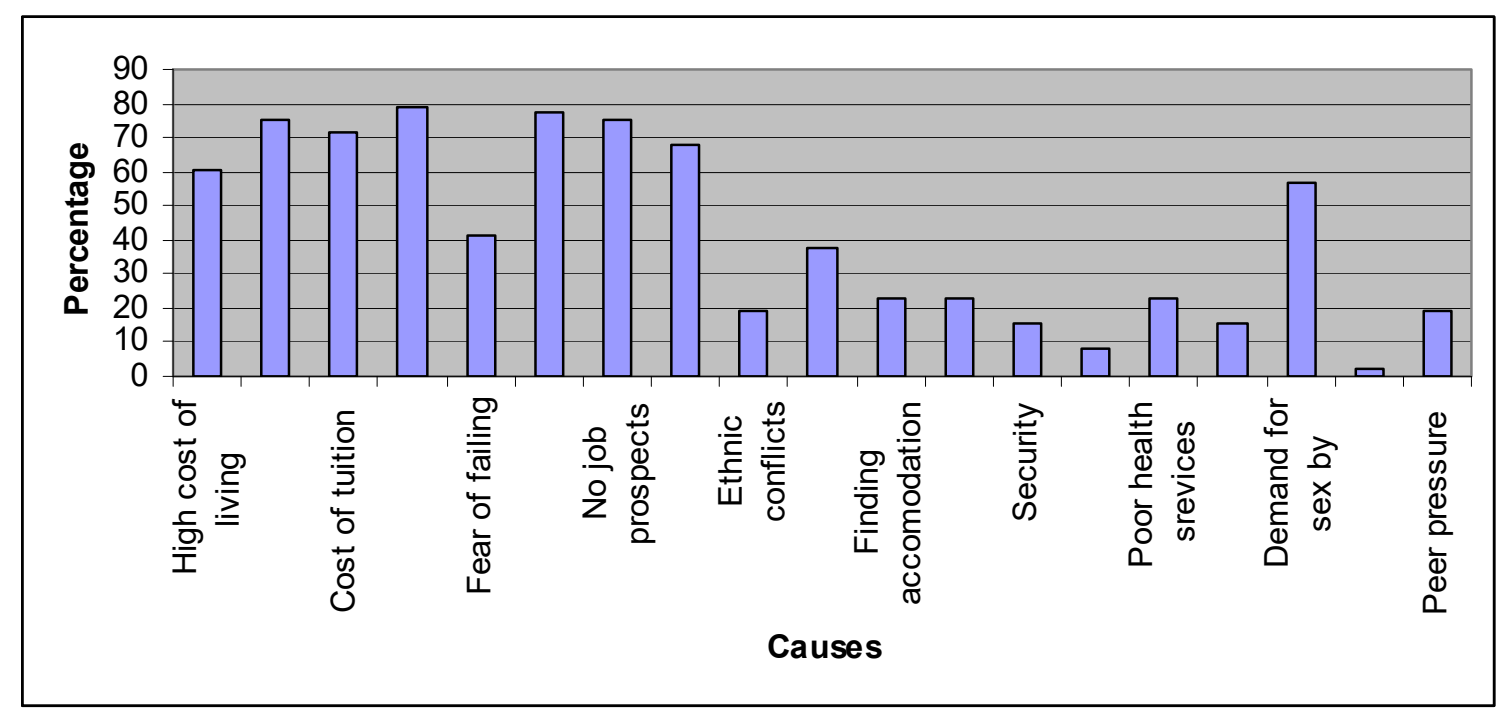

Figure 3. Causes of Stress Reported by Female Respondents

Among students who experienced low stress levels, 52 (25\%) had grade C, $113(54.33 \%)$ had grade B while $43(20.67 \%)$ had grade A. 49(30.6\%) of the students who experienced moderate stress levels had grade $\mathrm{C}, 83(51.9 \%)$ had grade B and $28(17.5 \%)$ had grade A. 81 (37.5\%) of the students who experienced high stress levels had grade C, 105(48.6\%) had grade B while $30(13.9 \%)$ had grade A. Results from the Pearson chi-square show that stress has a statistically significant relationship with academic performance $\left(\chi^{2}=9.49, \mathrm{n}=584, \mathrm{df}=4\right.$ $p=0.048)$. The relationship between stress and academic performance was tested further using Cramer's V $\left(\Phi_{c}\right)$. Cramer's V adjusts the $\chi^{2}$ significance to factor out sample size because $\chi^{2}$ coefficient depends on the strength of the relationship and the sample size. Cramer's V analysis was done and the results $\left(\Phi_{\mathrm{c}}=0.228, p=0.048\right)$ indicate that stress has a moderate but significant association with academic performance. The results show that higher levels of stress were associated with poor academic performance.

\section{Age as a factor in how stress relates to academic performance}

Table 2 below presents a $\chi^{2}$ analysis of the role of age in the relationship between stress and academic performance. Within 19-22 years, 42 (35.9\%) students who experienced low stress levels had grade C, 60 (51.3\%) had grade B while 15(12.8\%) had grade A. 21(29.2\%) of the students who experienced moderate stress levels had grade C, $41(56.9 \%)$ had -grade B, while $10(13.9 \%)$ had grade A. Among the students who experienced high stress levels, 38(31.9\%) had grade C, $56(47.1 \%)$ had grade B and $25(21.0 \%)$ had grade A. The results indicate that 


\section{Macrothink}

International Journal of Learning and Development

ISSN 2164-4063

2018, Vol. 8, No. 4

stress and academic performance are significantly related within 19-22 years $\left(\chi^{2}=8.34, \mathrm{n}=\right.$ $308, \mathrm{df}=4, \mathrm{p}=0.049 ; \Phi_{\mathrm{c}}=0.216, p=0.049$ ).

When considered within 23-26 years, 19(24.4\%) students who experienced low stress levels had grade C, 47(60.3\%) had grade B while $12(15.4 \%)$ had grade A. Among students who experienced moderate stress levels, 27(33.75\%) had grade C, $39(48.75 \%)$ had B and $14(17.5 \%)$ had grade A. 33(35.87\%) students who experienced high stress levels had grade C, $45(48.91 \%)$ had grade B while $14(15.22 \%)$ had grade A.

Table 2. Effect of Age on the relationship between the Students' Stress Level and Academic Performance

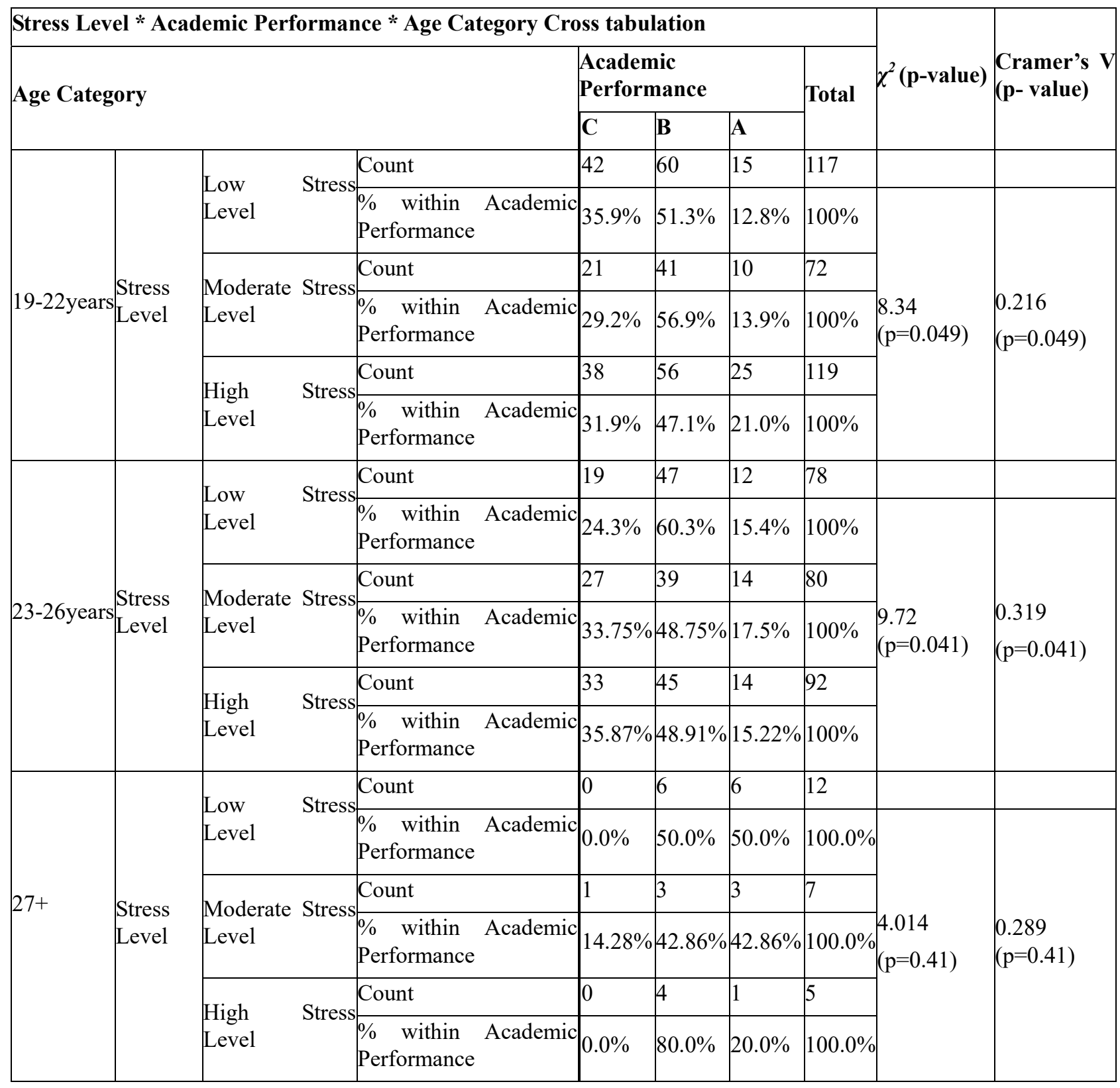




\section{Macrothink}

International Journal of Learning and Development

ISSN 2164-4063 2018, Vol. 8, No. 4

The results suggest that the relationship between stress and academic performance is statistically significant within this age group $\left(\chi^{2}=9.72, \mathrm{n}=250, \mathrm{df}=4, \mathrm{p}=0.041 ; \Phi_{\mathrm{c}}=0.319\right.$, $p=0.041)$. The results for both age groups indicate that age mediates the relationship between stress and academic performance. Older students appear to be better at dealing with their problems and consequently minimize the effects of stress on their academic work.

\section{Gender As a Factor in How Stress Relates to Academic Performance}

Table 3 shows $\chi^{2}$ analysis of the role of gender in the relationship between stress and academic performance. $26(26 \%)$ of the male students who experienced low stress levels had grade C compared to 59(59\%) who had grade B and 15(15\%) who had grade A. $27(28.42 \%)$ of the male students who reported moderate stress levels had grade $\mathrm{C}$ compared to 51(53.68\%) who had grade B and 17(17.89\%) who had grade A. 38(30.65\%) of the male students who experienced high stress levels had grade $\mathrm{C}$ while 67 (54.03\%) had grade B and $19(15.32 \%)$ had grade A.

Among the female students, $36(33.33 \%)$ who experienced low stress levels had grade $\mathrm{C}$ while 54 (50\%) had grade B and $18(16.67 \%)$ had grade A. 22(33.84\%) female students who had moderate stress levels had grade $\mathrm{C}$ while $32(49.23 \%)$ had grade B and $11(16.92 \%)$ had grade A. 33 (35.87\%) female students who experienced high stress levels had grade $\mathrm{C}$ while $38(41.30 \%)$ had grade B and $21(22.82 \%)$ had grade A. A Across the categories, the relationship between stress and academic performance are statistically significant among both male $\left(\chi^{2}=12.18, \mathrm{n}=319, \mathrm{df}=4, p=0.025\right)$ and female $\left(\chi^{2}=9.74, \mathrm{n}=265, \mathrm{df}=4, p=0.049\right)$ respondents. Cramer's V among both males $\left(\Phi_{\mathrm{c}}=0.221, p=0.025\right)$ and female $\left(\Phi_{\mathrm{c}}=0.35\right.$, $p=0.049)$ respondents show that the relationship between stress and academic performance have statistically significant moderate and strong association respectively.

Table 3. Effect of Gender on the Relationship between the Students' Stress level and Academic Performance

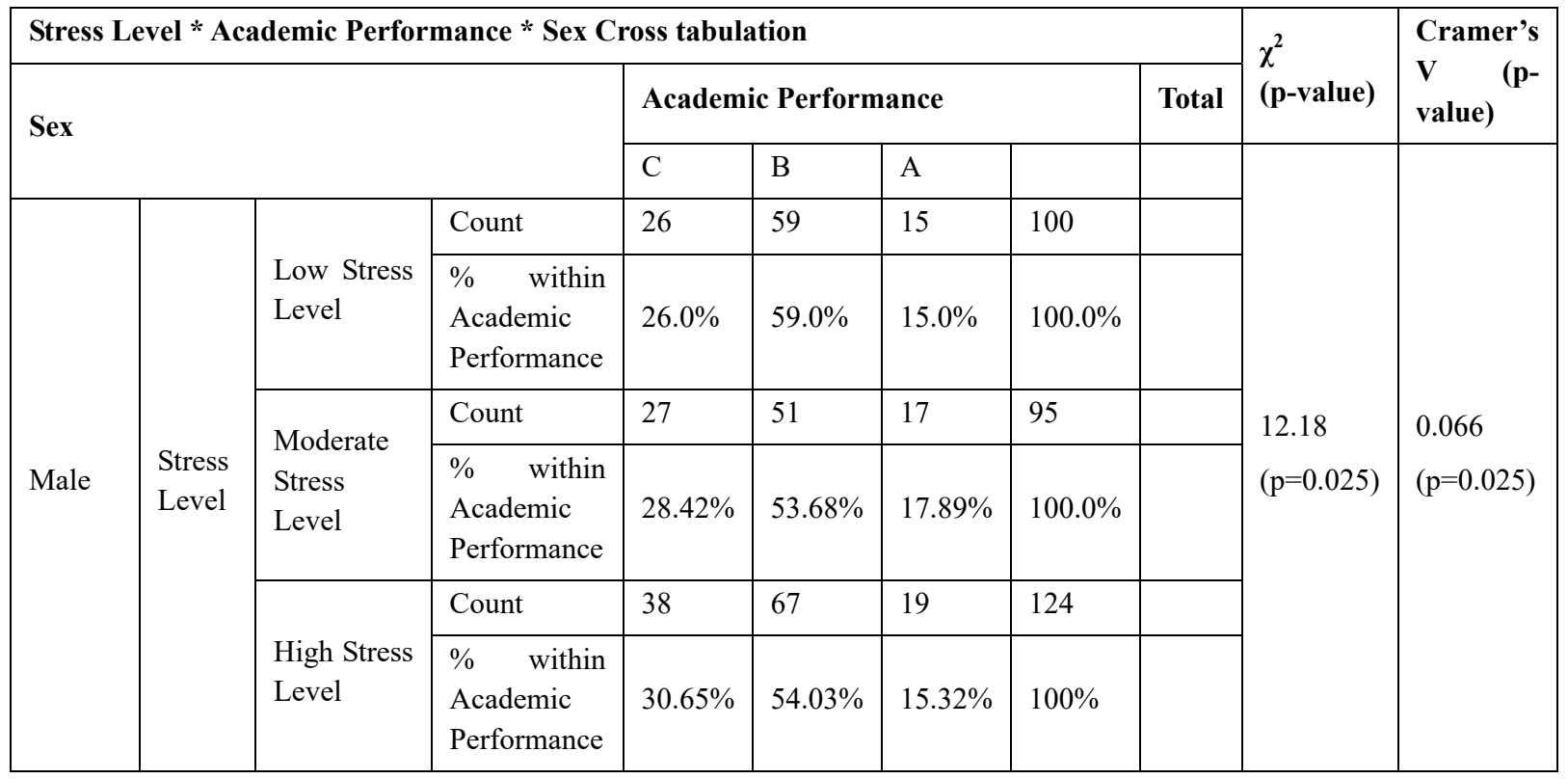




\section{MInstitute Macrothink}

\begin{tabular}{|c|c|c|c|c|c|c|c|c|c|}
\hline \multirow{6}{*}{ Female } & \multirow{6}{*}{$\begin{array}{l}\text { Stress } \\
\text { Level }\end{array}$} & \multirow[b]{2}{*}{$\begin{array}{l}\text { Low Stress } \\
\text { Level }\end{array}$} & Count & 36 & 54 & 18 & 108 & \multirow{6}{*}{$\begin{array}{l}9.74 \\
P=0.049\end{array}$} & \multirow{6}{*}{$\begin{array}{l}0.096 \\
p=0.049\end{array}$} \\
\hline & & & $\begin{array}{l}\% \text { within } \\
\text { Academic } \\
\text { Performance }\end{array}$ & $33.33 \%$ & $50.0 \%$ & $16.67 \%$ & $100.0 \%$ & & \\
\hline & & \multirow[b]{2}{*}{$\begin{array}{l}\text { Moderate } \\
\text { Stress } \\
\text { Level }\end{array}$} & Count & 22 & 32 & 11 & 65 & & \\
\hline & & & $\begin{array}{l}\% \text { within } \\
\text { Academic } \\
\text { Performance }\end{array}$ & $33.84 \%$ & $49.23 \%$ & $16.92 \%$ & $100.0 \%$ & & \\
\hline & & \multirow[b]{2}{*}{$\begin{array}{l}\text { High Stress } \\
\text { Level }\end{array}$} & Count & 33 & 38 & 21 & 92 & & \\
\hline & & & $\begin{array}{l}\text { \% within } \\
\text { Academic } \\
\text { Performance }\end{array}$ & $35.87 \%$ & $41.3 \%$ & $22.82 \%$ & $100.0 \%$ & & \\
\hline
\end{tabular}

\section{Course As a Factor in How Stress Relates to Academic Performance}

Table 4 shows $\chi^{2}$ analysis of course factor in the relationship between stress and academic performance. Among students from College of Health Sciences who reported experiencing low stress levels $10(45.46 \%)$ had grade C, 11(50.0\%) had grade B while only $1(4.54 \%)$ had A grade. $8(55.33 \%)$ of the students who experienced moderate stress levels had grade $\mathrm{C}$ and $7(46.67 \%)$ had grade B. $2 \mathrm{O}(50.05 \%)$ of the students who experienced high stress levels had grade C and 17 (45.95\%) had grade B grade. The relationship between stress and academic performance within this course category is, however, not statistically significant $\left(\chi^{2}=6.59, \mathrm{n}=74, \mathrm{df}=4, p=0.247 ; \Phi_{\mathrm{c}}=0.211, p=0.247\right)$.

Within College of Humanities and Social Sciences, 25 (33.33\%) students who experienced low stress levels had grade C, 31 (41.33\%) had grade B while 19 (25.33\%) had grade A. 11 (18.97\%) students who experienced moderate stress levels had grade C, 34 (58.62\%) had grade B while $13(22.41 \%)$ had grade A. Among the students who experienced high stress levels 23 (42.59\%) had grade C, 18 (33.33\%) had grade B while $13(24.07 \%)$ had grade A. The relationship between stress and academic performance is significant $\left(\chi^{2}=10.97, \mathrm{n}=187\right.$, $\left.\mathrm{df}=4, p=0.036 ; \Phi_{\mathrm{c}}=0.271, p=0.046\right)$

Within the College of Architecture and Engineering, 4 (20.0\%) students who experienced low stress levels had grade C, 13(65.0\%) had grade B while $3(15.0 \%)$ had grade A. 10(41.67\%) students who experienced moderate stress levels had grade C, 9 (37.5\%) had grade B while $5(20.83 \%)$ had grade A. Among the students who experienced high stress levels $11(40.74 \%)$ had grade C, 10 (37.04\%) had grade B while $6(22.22 \%)$ had grade A. The relationship between stress and academic performance is not significant $\left(\chi^{2}=6.216, \mathrm{n}=71\right.$, $\left.\mathrm{df}=4, p=0.216 ; \Phi_{\mathrm{c}}=0.207, p=0.216\right)$

Within the College of Biological and Physical Sciences, 5 (21.74\%) students who experienced low stress levels had grade C, 14 (60.87\%) had grade B while 4 (17.39\%) had A. Among the students who experienced moderate stress levels, 7 (33.33\%) had grade $\mathrm{C}, 8$ (38.09\%) had grade B while $6(28.57 \%)$ had grade A. 12(21.43\%) students who experienced high stress levels had grade C, 28(50.0\%) had grade B while $16(28.57 \%)$ had grade A The 


\section{Macrothink}

International Journal of Learning and Development

ISSN 2164-4063

2018, Vol. 8, No. 4

relationship between stress level and academic performance is not significant $\left(\chi^{2}=3.818\right.$, $\left.\mathrm{n}=100, \mathrm{df}=4, p=0.701 ; \Phi_{\mathrm{c}}=0.0 .138, p=0.701\right)$.

Within the College of Agriculture and Veterinary Sciences, 3(14.29\%) students who experienced low stress levels had grade C and 18 (85.71\%) had grade B. $9(42.86 \%)$ students who experienced moderate stress levels had grade C, $10(47.62 \%)$ had grade B while $2(9.52 \%)$ had grade A. Among the students who experienced high stress levels, $1(6.25 \%)$ student had grade A, $12(75.0 \%)$ had grade B while 3(18.75\%) had grade A. The relationship between stress level and academic performance is highly significant $\left(\chi^{2}=12.46, \mathrm{n}=58, \mathrm{df}=4\right.$, $\left.p=0.014 ; \Phi_{\mathrm{c}}=0.328, p=0.014\right)$

Within the College of Education and External Studies, 15 (31.91\%) students who experienced low stress levels had grade C, $26(55.32 \%)$ had grade B while $6(12.77 \%)$ had grade A. 4 (19.05\%) students who experienced moderate stress levels had grade C, $15(71.43 \%)$ had grade B while 2 ( 9.52\%) had grade A. Among the students who experienced high stress levels, 4 (15.38\%) had grade C, 20(76.92\%) had grade B while $2(7.69 \%)$ had grade A

Table 4. Effect of Course on the Relationship between the Students' Stress Levels and Academic Performance

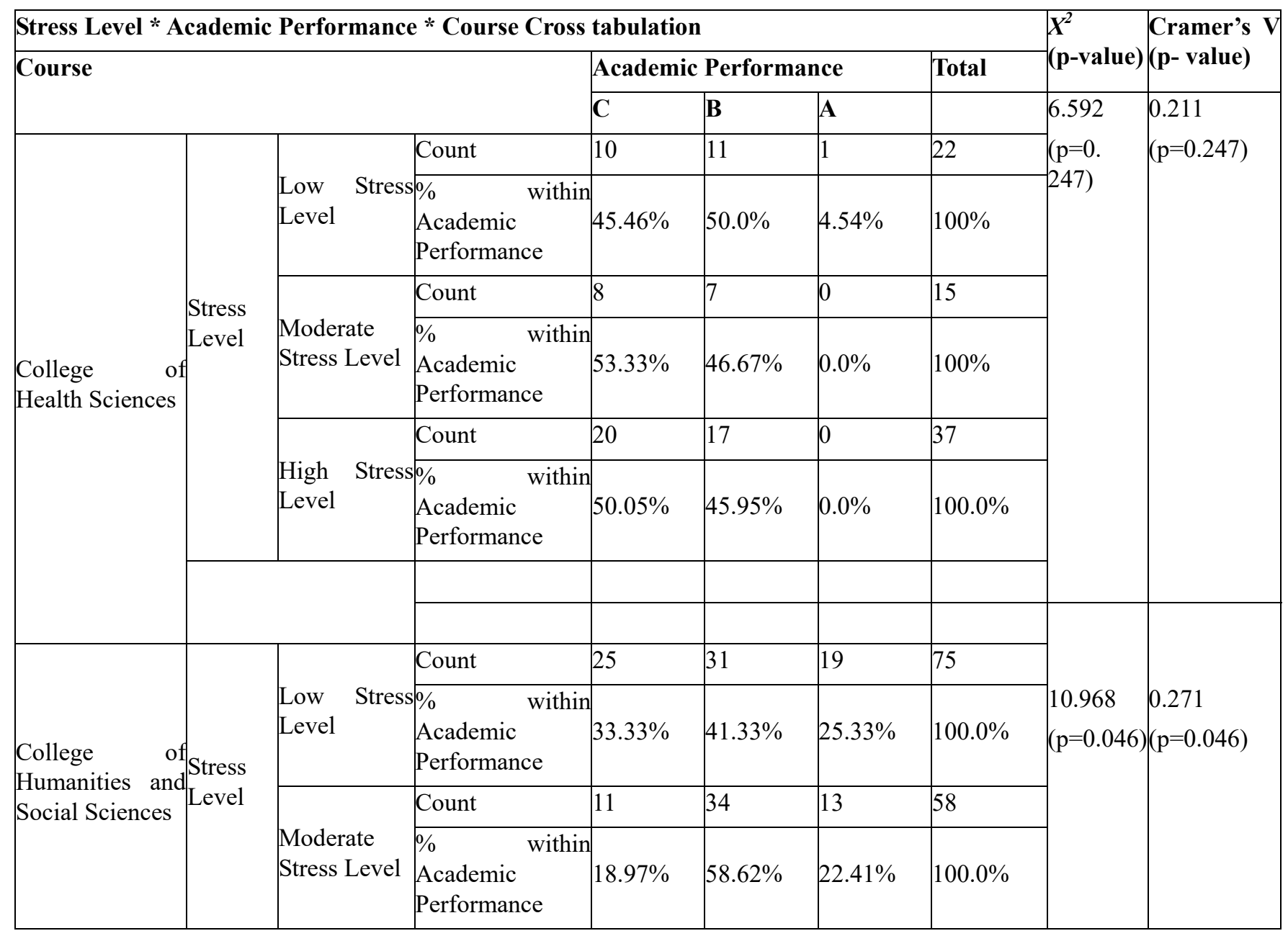




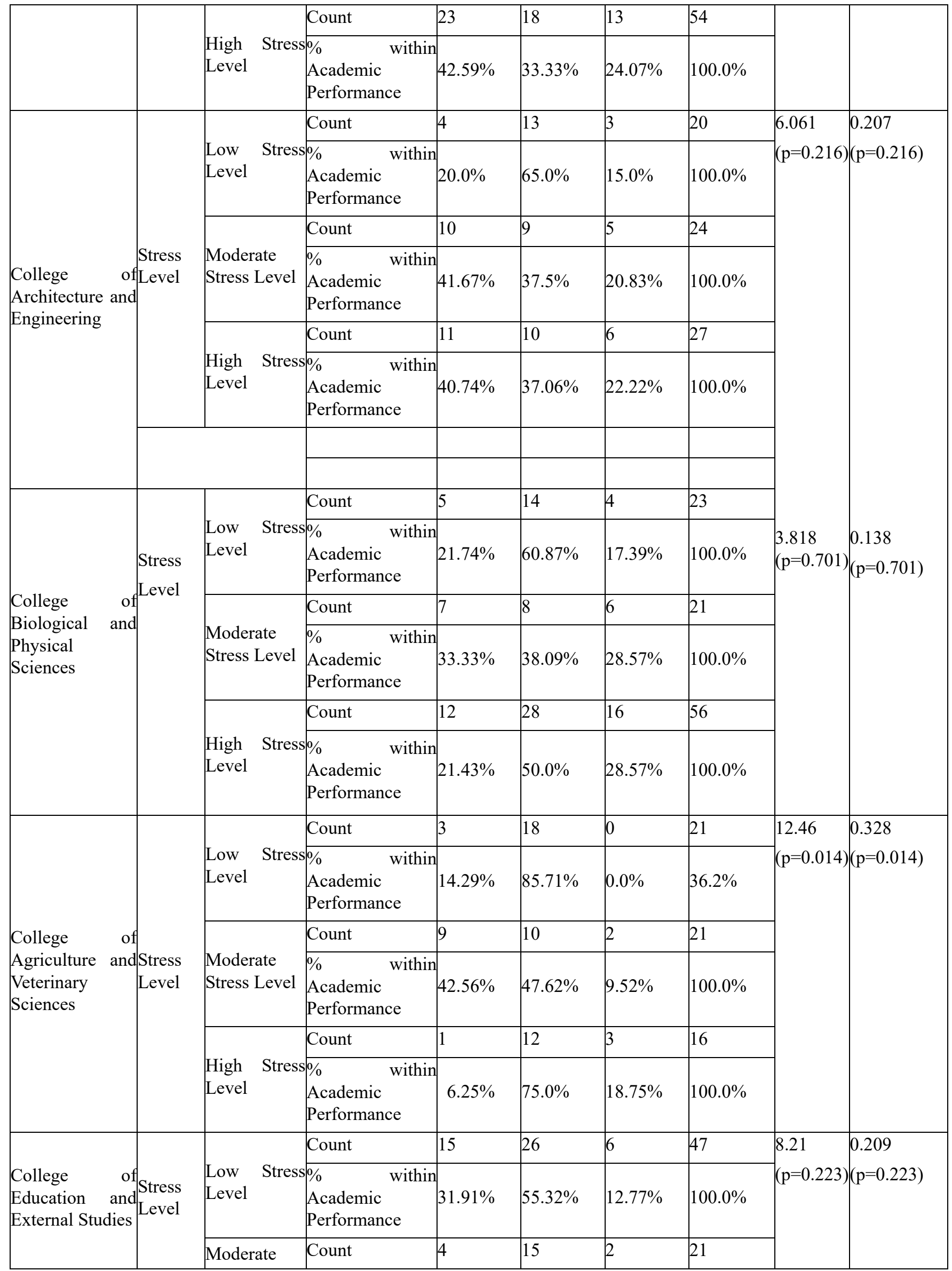




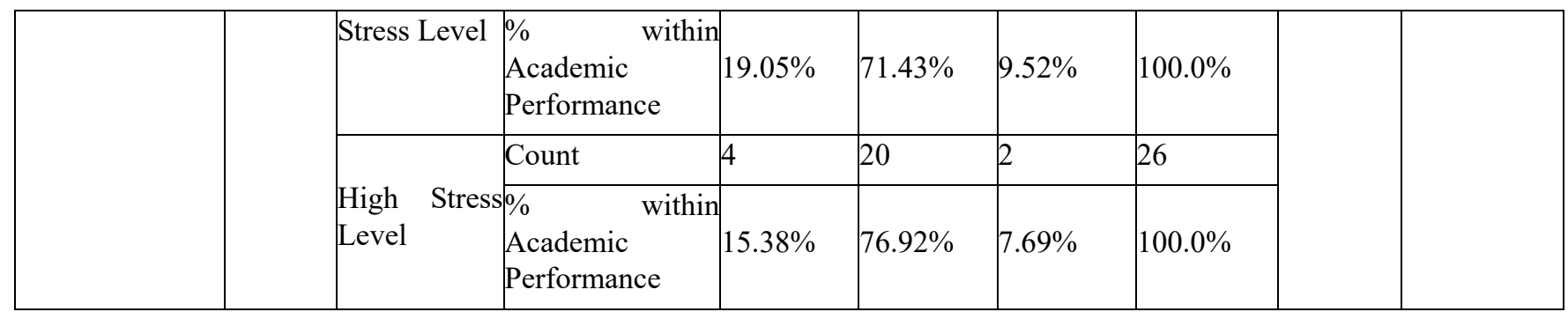

The results of the chi-square analysis show that the relationship between stress and academic performance are statistically significant among students taking humanities and social sciences $\left(\chi^{2}=10.97, \mathrm{df}=4, p=0.046\right)$ and those taking agriculture and veterinary sciences $\left(\chi^{2}\right.$ $=12.46, \mathrm{df}=4, \mathrm{p}=0.014)$. The Cramer's $\mathrm{V}$ for the humanities and social sciences is 0.271 ( $p=0.04$ The relationship between stress and academic performance is not significant $\left(\chi^{2}=8.21, \mathrm{n}=94 \mathrm{df}=4, p=8.21 ; \Phi_{\mathrm{c}}=0.209, p=0.223\right)$.

\section{Levels of Study as a factor in how stress relates to academic performance}

Table 5 shows a $\chi^{2}$ analysis of the role of level of study in the relationship between stress and academic performance. In level 1, 6(31.58\%) students who experienced low stress levels had grade C, 8 (42.11\%) had grade B while 5 (26.32\%) had grade A. Among the students who experienced moderate stress levels, $5(16.13 \%)$ had grade C, $18(58.06 \%)$ had grade B while 8 (25.81\%) got grade A. 13 (43.33\%) students who experienced high stress level had grade C, $8(26.67 \%)$ had grade B while $9(30.0 \%)$ had grade A. The relationship between stress and academic performance is significant $\left(\chi^{2}=9.56, \mathrm{n}=80, \mathrm{df}=4, p=0.048 ; \Phi_{\mathrm{c}}=0.224, p=0.048\right)$

Within level 2, 29(30.21\%) students who experienced low stress levels had grade C, 53 (55.21\%) had grade B while 14 (14.58\%) had grade A. Among the students who experienced moderate stress levels, 9(21.43\%) had grade C, 27 (64.29\%) had grade B while 6(14.29\%) had grade A.21 (28.39\%) students who experienced high stress levels had grade C, 41 (55.41\%) students had grade B while $12(16.22 \%)$ had grade A. The relationship between stress and academic performance was not significant $\left(\chi^{2}=5.78, \mathrm{n}=212, \mathrm{df}=4, p=0.27 ; \Phi_{\mathrm{c}}\right.$ $=0.177, p=0.27$ ).

Within level 3, 17 (26.15\%) students who experienced low stress levels had grade C, 39 (60.0\%) had grade B while 9 (13.85\%) had grade A. 22 (39.93\%) students who experienced moderate stress levels had grade C, 26(44.83\%) students had grade B while 10(17.24\%) had grade A. Among the students who experienced high stress levels, 25 (36.76\%) had grade C, 31 (45.59\%) students had grade B while 12 (17.65\%) had grade A. The relationship between stress and academic performance is not significant $\left(\chi^{2}=3.944, \mathrm{n}=191, \mathrm{df}=4, p=0.48 ; \Phi_{\mathrm{c}}\right.$ $=\mathrm{O} .102, p=0.48)$.

Within level 4 8(40.0\%) students who experienced low stress levels had grade C, 7 (35.0\%) had grade B while $5(25.0 \%)$ had grade A. Among the students who experienced moderate stress levels, 12 (44.44\%) had grade C, 11(40.74\%) had grade B while 4(14.81\%) had grade A. 12 (33.33\%) students who experienced high stress levels had grade C, 17(47.22\%) had grade B while $7(19.44 \%)$ had grade A. The relationship between stress and academic 


\section{Macrothink}

performance is highly significant $\left(\chi^{2}=13.44, \mathrm{n}=83, \mathrm{df}=4, p=0.015 ; \Phi_{\mathrm{c}}=0.244 . p=0.015\right)$.

Within level 5, 2 (25.0\%) students who experienced low stress levels had grade C, 6(75.0\%) had grade B. Among students who experienced moderate stress levels, 1 (50.0\%) student had grade $\mathrm{C}$ while another $1(50.0 \%)$ had grade $\mathrm{B}$. All the 8 students who experienced high stress level got grade $\mathrm{B}$. The relationship between stress and academic performance is not significant $\left(\chi^{2}=3.6, \mathrm{n}=18, \mathrm{df}=2, p=0.46 ; \Phi_{\mathrm{c}}=0.447, p=0.46\right)$.

Table 5. Effect of Levels of Study on the Relationship between the Students' Stress Level and Academic Performance

\begin{tabular}{|c|c|c|c|c|c|c|c|c|c|c|}
\hline \multicolumn{9}{|c|}{ Stress Level * Academic Performance * Year of study Cross tabulation } & \multirow{2}{*}{$\chi^{2}$ (p-value) } & \multirow{2}{*}{$\begin{array}{l}\text { Cramer's V } \\
\text { (p- value) }\end{array}$} \\
\hline \multirow{2}{*}{\multicolumn{4}{|c|}{ Year of study }} & \multicolumn{4}{|c|}{ Academic Performance } & \multirow[t]{2}{*}{ Total } & & \\
\hline & & & & $\mathrm{C}$ & B & A & & & \multirow{7}{*}{$\begin{array}{l}9.56 \\
(p=0.048)\end{array}$} & \multirow{7}{*}{$\begin{array}{l}0.224 \\
(p=0.048)\end{array}$} \\
\hline \multirow{6}{*}{1} & \multirow{6}{*}{$\begin{array}{l}\text { Stress } \\
\text { Level }\end{array}$} & \multirow[b]{2}{*}{$\begin{array}{l}\text { Low } \\
\text { Stress } \\
\text { Level }\end{array}$} & Count & 6 & 8 & 5 & 19 & & & \\
\hline & & & $\begin{array}{l}\% \text { within } \\
\text { Academic } \\
\text { Performance }\end{array}$ & $31.58 \%$ & $42.11 \%$ & $26.32 \%$ & $100.0 \%$ & & & \\
\hline & & \multirow[b]{2}{*}{$\begin{array}{l}\text { Moderate } \\
\text { Stress } \\
\text { Level }\end{array}$} & Count & 5 & 18 & 8 & 31 & & & \\
\hline & & & $\begin{array}{l}\text { \% within } \\
\text { Academic } \\
\text { Performance }\end{array}$ & $16.13 \%$ & $58.08 \%$ & $25.81 \%$ & $100.0 \%$ & & & \\
\hline & & \multirow[b]{2}{*}{$\begin{array}{l}\text { High } \\
\text { Stress } \\
\text { Level }\end{array}$} & Count & 13 & 8 & 9 & 30 & & & \\
\hline & & & $\begin{array}{l}\% \text { within } \\
\text { Academic } \\
\text { Performance }\end{array}$ & $43.33 \%$ & $26.67 \%$ & $30.0 \%$ & $100.0 \%$ & & & \\
\hline \multirow{6}{*}{2} & \multirow{6}{*}{$\begin{array}{l}\text { Stress } \\
\text { Level }\end{array}$} & \multirow[b]{2}{*}{$\begin{array}{l}\text { Low } \\
\text { Stress } \\
\text { Level }\end{array}$} & Count & 29 & 53 & 14 & 96 & & \multirow{10}{*}{$\begin{array}{l}5.78 \\
(p=0.27)\end{array}$} & \multirow{10}{*}{$\begin{array}{l}0.177 \\
(p=0.27)\end{array}$} \\
\hline & & & $\begin{array}{l}\% \text { within } \\
\text { Academic } \\
\text { Performance }\end{array}$ & $30.21 \%$ & $55.21 \%$ & $14.58 \%$ & $100.0 \%$ & & & \\
\hline & & \multirow[b]{2}{*}{$\begin{array}{l}\text { Moderate } \\
\text { Stress } \\
\text { Level }\end{array}$} & Count & 9 & 27 & 6 & 42 & & & \\
\hline & & & $\begin{array}{l}\% \text { within } \\
\text { Academic } \\
\text { Performance }\end{array}$ & $21.43 \%$ & $64.29 \%$ & $14.29 \%$ & $100.0 \%$ & & & \\
\hline & & \multirow[b]{2}{*}{$\begin{array}{l}\text { High } \\
\text { Stress } \\
\text { Level }\end{array}$} & Count & 21 & 41 & 12 & 74 & & & \\
\hline & & & $\begin{array}{l}\text { \% within } \\
\text { Academic } \\
\text { Performance }\end{array}$ & $28.39 \%$ & $55.41 \%$ & $16.22 \%$ & $100.0 \%$ & & & \\
\hline \multirow{4}{*}{3} & \multirow{4}{*}{$\begin{array}{l}\text { Stress } \\
\text { Level }\end{array}$} & \multirow[b]{2}{*}{$\begin{array}{l}\text { Low } \\
\text { Stress } \\
\text { Level }\end{array}$} & Count & 17 & 39 & 9 & 65 & & & \\
\hline & & & $\begin{array}{l}\% \text { within } \\
\text { Academic } \\
\text { Performance }\end{array}$ & $26.15 \%$ & $60.0 \%$ & $13.85 \%$ & $100.0 \%$ & & & \\
\hline & & \multirow[b]{2}{*}{$\begin{array}{l}\text { Moderate } \\
\text { Stress } \\
\text { Level }\end{array}$} & Count & 22 & 26 & 10 & 58 & & & \\
\hline & & & $\begin{array}{l}\% \text { within } \\
\text { Academic } \\
\text { Performance }\end{array}$ & $39.93 \%$ & $44.83 \%$ & $17.24 \%$ & $100.0 \%$ & & & \\
\hline
\end{tabular}


M Macrothink

International Journal of Learning and Development

ISSN 2164-4063

2018, Vol. 8, No. 4

\begin{tabular}{|c|c|c|c|c|c|c|c|c|c|}
\hline & & \multirow[b]{2}{*}{$\begin{array}{l}\text { High } \\
\text { Stress } \\
\text { Level }\end{array}$} & Count & \multirow{2}{*}{$\begin{array}{l}25 \\
36.76 \%\end{array}$} & \multirow{2}{*}{$\begin{array}{l}31 \\
45.59 \%\end{array}$} & \multirow{2}{*}{$\begin{array}{l}12 \\
17.65 \%\end{array}$} & \multirow{2}{*}{$\begin{array}{l}68 \\
100.0 \%\end{array}$} & \multirow{2}{*}{$\begin{array}{l}3.944 \\
(p=0.48)\end{array}$} & \multirow{2}{*}{$\begin{array}{l}0.102 \\
(p=0.48)\end{array}$} \\
\hline & & & $\begin{array}{l}\% \text { within } \\
\text { Academic } \\
\text { Performance }\end{array}$ & & & & & & \\
\hline \multirow{8}{*}{4} & \multirow{6}{*}{$\begin{array}{l}\text { Stress } \\
\text { Level }\end{array}$} & \multirow{2}{*}{$\begin{array}{l}\text { Low } \\
\text { Stress } \\
\text { Level }\end{array}$} & Count & 8 & 7 & 5 & 20 & \multirow{7}{*}{$\begin{array}{l}13.44 \\
(p=0.015)\end{array}$} & \multirow{7}{*}{$\begin{array}{l}0.244 \\
(p=0.015)\end{array}$} \\
\hline & & & $\begin{array}{l}\% \text { within } \\
\text { Academic } \\
\text { Performance }\end{array}$ & $40.0 \%$ & $35.0 \%$ & $25.0 \%$ & $100.0 \%$ & & \\
\hline & & \multirow[b]{2}{*}{$\begin{array}{l}\text { Moderate } \\
\text { Stress } \\
\text { Level }\end{array}$} & Count & 12 & 11 & 4 & 27 & & \\
\hline & & & $\begin{array}{l}\text { \% within } \\
\text { Academic } \\
\text { Performance }\end{array}$ & $44.44 \%$ & $40.74 \%$ & $14.81 \%$ & $100.0 \%$ & & \\
\hline & & \multirow{2}{*}{$\begin{array}{l}\text { High } \\
\text { Stress } \\
\text { Level }\end{array}$} & Count & 12 & 17 & 7 & 36 & & \\
\hline & & & $\begin{array}{l}\text { \% within } \\
\text { Academic } \\
\text { Performance }\end{array}$ & $33.33 \%$ & $47.22 \%$ & $19.44 \%$ & $100.0 \%$ & & \\
\hline & \multirow{2}{*}{\multicolumn{2}{|c|}{ Total }} & Count & 32 & 35 & 16 & 83 & & \\
\hline & & & $\begin{array}{l}\% \text { within } \\
\text { Academic } \\
\text { Performance }\end{array}$ & $100.0 \%$ & $100.0 \%$ & $100.0 \%$ & $100.0 \%$ & & \\
\hline \multirow{6}{*}{5} & \multirow{6}{*}{$\begin{array}{l}\text { Stress } \\
\text { Level }\end{array}$} & \multirow{2}{*}{$\begin{array}{l}\text { Low } \\
\text { Stress } \\
\text { Level }\end{array}$} & Count & 2 & 6 & 0 & 8 & \multirow{6}{*}{$\begin{array}{l}3.6 \\
(p=0.46)\end{array}$} & \multirow{6}{*}{$\begin{array}{l}0.447 \\
(p=0.46)\end{array}$} \\
\hline & & & $\begin{array}{l}\% \text { within } \\
\text { Academic } \\
\text { Performance }\end{array}$ & $25.0 \%$ & $75.0 \%$ & 0.0 & $100 / 0 \%$ & & \\
\hline & & & Count & 1 & 1 & 0 & 2 & & \\
\hline & & $\begin{array}{l}\text { Stress } \\
\text { Level }\end{array}$ & $\begin{array}{l}\% \text { within } \\
\text { Academic } \\
\text { Performance }\end{array}$ & $50.0 \%$ & $50.0 \%$ & 0.0 & $100.0 \%$ & & \\
\hline & & \multirow{2}{*}{$\begin{array}{l}\text { High } \\
\text { Stress } \\
\text { Level }\end{array}$} & Count & 0 & 8 & & 8 & & \\
\hline & & & $\begin{array}{l}\% \text { within } \\
\text { Academic } \\
\text { Performance }\end{array}$ & $0.0 \%$ & $100.0 \%$ & & $100.0 \%$ & & \\
\hline
\end{tabular}

\section{Locus of Control as a factor in how stress relates to academic performance}

The $\chi^{2}$ analysis of the role of locus of control in the relationship between stress and academic performance presented in Table 6.. Among students with internal locus of control, 21(23.08\%) students who experienced low stress levels had grade C, 44(48.35\%) had grade B while 26(28.57\%) had grade A. $15(22.06 \%)$ students who experienced moderate stress levels had grade C, 43 (67.65\%) had grade B while 10 (14.71\%) had grade A. Among students who experienced high stress level, 40(41.24\%) had grade C, 49(50.52\%) had grade B while $8(8.25 \%)$ had grade A. The relationship between stress and academic performance is highly significant within internal locus of control $\left(\chi^{2}=21.74, \mathrm{n}=256, \mathrm{df}=4, \quad p=0.001 ; \quad \Phi_{\mathrm{c}}=0.329\right.$, $p=0.001$ )

Within external locus of control, 51(43.59\%) students who experienced low stress got grade 


\section{Macrothink}

International Journal of Learning and Development ISSN 2164-4063 2018, Vol. 8, No. 4

C, 49(41.88\%) got grade B while 17(14.53\%) got grade A. Among students who experienced moderate stress $24(26.09 \%)$ got grade C, 50(54.35\%) got grade B while $18(19.57 \%)$ students got grade A. $51(39.53 \%)$ students who experienced high stress levels got grade C, $56(43.41 \%)$ got grade B while 22(17.05\%) got grade A. The relationship between stress and academic performance is significant $\left(\chi^{2}=10.57, \mathrm{n}=328, \quad \mathrm{df}=4, \quad p=0.047 ; \quad \Phi_{\mathrm{c}}=0.372\right.$, $p=0.047)$.

Table 6. Effect of Locus of Control on the Students' Stress Level and Academic Performance

\begin{tabular}{|c|c|c|c|c|c|c|c|c|c|c|}
\hline \multicolumn{9}{|c|}{ Stress Level * Academic Performance * Locus of Control Cross tabulation } & \multirow{2}{*}{$\begin{array}{l}\chi^{2} \\
\text { (p-value) }\end{array}$} & \multirow{2}{*}{$\begin{array}{l}\text { Cramer's } \\
\text { V (p- } \\
\text { value) }\end{array}$} \\
\hline \multirow{2}{*}{\multicolumn{4}{|c|}{ Locus of Control }} & \multicolumn{4}{|c|}{ Academic Performance } & \multirow[t]{2}{*}{ Total } & & \\
\hline & & & & $\mathbf{C}$ & B & $\mathbf{A}$ & & & \multirow{7}{*}{$\begin{array}{l}21.74 \\
p=0.001\end{array}$} & \multirow{7}{*}{$\begin{array}{l}0.329 \\
(p=0.001)\end{array}$} \\
\hline \multirow{6}{*}{$\begin{array}{l}\text { Internal } \\
\text { Locus } \\
\text { of } \\
\text { Control }\end{array}$} & \multirow{6}{*}{$\begin{array}{l}\text { Stress } \\
\text { Level }\end{array}$} & \multirow[b]{2}{*}{$\begin{array}{l}\text { Low } \\
\text { Stress } \\
\text { Level }\end{array}$} & Count & 21 & 44 & 26 & 91 & & & \\
\hline & & & $\begin{array}{l}\% \text { within } \\
\text { Academic } \\
\text { Performance }\end{array}$ & $23.08 \%$ & $48.35 \%$ & $28.57 \%$ & $100 . \%$ & & & \\
\hline & & \multirow[b]{2}{*}{$\begin{array}{l}\text { Moderate } \\
\text { Stress } \\
\text { Level }\end{array}$} & Count & 15 & 43 & 10 & 68 & & & \\
\hline & & & $\begin{array}{l}\% \text { within } \\
\text { Academic } \\
\text { Performance }\end{array}$ & $22.06 \%$ & $63.24 \%$ & $14.70 \%$ & $100 \%$ & & & \\
\hline & & \multirow[b]{2}{*}{$\begin{array}{l}\text { High } \\
\text { Stress } \\
\text { Level }\end{array}$} & Count & 40 & 49 & 8 & 97 & & & \\
\hline & & & $\begin{array}{l}\% \text { within } \\
\text { Academic } \\
\text { Performance }\end{array}$ & $41.24 \%$ & $50.52 \%$ & $8.25 \%$ & $100 \%$ & & & \\
\hline \multirow{6}{*}{$\begin{array}{l}\text { External } \\
\text { Level of } \\
\text { Control }\end{array}$} & \multirow{6}{*}{$\begin{array}{l}\text { Stress } \\
\text { Level }\end{array}$} & \multirow[b]{2}{*}{$\begin{array}{l}\text { Low } \\
\text { Stress } \\
\text { Level }\end{array}$} & Count & 51 & 49 & 17 & 117 & & \multirow{6}{*}{$\begin{array}{l}10.566 \\
p=0.047\end{array}$} & \multirow{6}{*}{$\begin{array}{l}0.372 \\
(p=0.047)\end{array}$} \\
\hline & & & $\begin{array}{l}\% \text { within } \\
\text { Academic } \\
\text { Performance }\end{array}$ & $43.59 \%$ & $41.88 \%$ & $14.53 \%$ & $100 \%$ & & & \\
\hline & & \multirow[b]{2}{*}{$\begin{array}{l}\text { Moderate } \\
\text { Stress } \\
\text { Level }\end{array}$} & Count & 24 & 50 & 18 & 92 & & & \\
\hline & & & $\begin{array}{l}\% \text { within } \\
\text { Academic } \\
\text { Performance }\end{array}$ & $26.09 \%$ & $54.35 \%$ & $19.57 \%$ & $28.0 \%$ & & & \\
\hline & & \multirow[b]{2}{*}{$\begin{array}{l}\text { High } \\
\text { Stress } \\
\text { Level }\end{array}$} & Count & 51 & 56 & 22 & 129 & & & \\
\hline & & & $\begin{array}{l}\% \text { within } \\
\text { Academic } \\
\text { Performance }\end{array}$ & $39.53 \%$ & $43.41 \%$ & $17.05 \%$ & $100 \%$ & & & \\
\hline
\end{tabular}

In order to carry out a regression analysis, academic performance was measured as a dummy variable with 1 standing for excellent and 0 standing for poor academic performance. Stress level was measured as a categorical variable with 1, 2, and 3 representing "Low", "Moderate", and "High" stress levels respectively. The "Low" stress level was used as the reference point. The level of study was measured in years with, 1, 2, 3, 4, and 5 representing the "First", "Second", "Third", "Fourth" and "Fifth" year respectively. Gender was 
measured as a dummy with 1 standing for males and 0 standing for females. College was measured as a categorical variable with $1,2,3,4,5$, and 6 representing "CHSS", "CBPS", "CEES", "CHS”, "CAE”, and "CAVS" respectively.

Table 7. Regression results for the effect of stress level on academic performance

\begin{tabular}{llllll}
\hline Academic performance & $\boldsymbol{\beta}$ & $\boldsymbol{S E} \boldsymbol{\beta}$ & $\boldsymbol{t}$-statistic & $\boldsymbol{P}$-Value & $\mathbf{9 5 \%} \boldsymbol{C I}$ \\
\hline Constant & .2104 & .1099 & 1.91 & .0560 & {$[-.00511, .42596]$} \\
\hline Stress level & & & & & \\
Moderate & -.2037 & .1435 & -1.42 & .1560 & {$[-.4849, .0775]$} \\
High & $-.2285^{* *}$ & .1332 & -1.72 & .0860 & {$[-.4895, .0326]$} \\
\hline
\end{tabular}

$R^{2} .0038$; No. of observations : 584 .

Note. ${ }^{* *}$ means statistically significant at the $10 \%$ level of significance.

Table 7 shows the regression results for the effect of stress level on academic performance. The estimated model had a small $\mathrm{R}^{2}=.0038$. Since the data has cross-sectional properties, small $\mathrm{R}^{2}$ is not a major concern as it could have been if the data was time series. The small $\mathrm{R}^{2}$ means that there are very many other variables that influence academic performance that were not included in the simple regression model that was estimated. Identifying and including those variables could increase the size of the $\mathrm{R}^{2}$ reported.

The results indicate that the students experiencing the "Moderate" and "High" stress levels are less likely to have excellent academic performance compared to students with "Low" stress level as indicated by the negative signs respectively. The negative effect of the "Moderate" stress level on academic performance was, however, not statistically significant $(\mathrm{t}=-1.42, \mathrm{p}=.1560)$. The negative effect of the "High" stress level on academic performance was statistically significant at the $10 \%$ level of significance $(\mathrm{t}=-1.72, \mathrm{p}=0.0860)$. The inference that can be drawn from this observation is that the higher the stress level, the poorer is the academic performance. Stress can thus be said to influence academic performance.

Table 8. Marginal effects of stress level on academic performance

\begin{tabular}{|c|c|c|c|c|c|}
\hline Academic performance & $\beta$ & SE $\beta$ & t-statistic & P-Value & $95 \% \mathrm{CI}$ \\
\hline \multicolumn{6}{|l|}{ Stress level } \\
\hline Moderate & -.0806 & .0565 & -1.43 & .1540 & {$[-.1914, .0301]$} \\
\hline High & $-.0905 * *$ & .0523 & -1.73 & .0840 & {$[-.1931,, .0121]$} \\
\hline
\end{tabular}

Table 8 presents the marginal effects of stress level on academic performance. Specifically, students experiencing the "Moderate" stress level are $8.06 \%$ less likely to attain excellent academic performance compared to those experiencing the "Low" stress level. The marginal effect is however, not statistically significant $(\mathrm{t}=-1.43, \mathrm{p}=.1540)$. Students experiencing the "High" stress level, on the other hand, are $9.05 \%$ less likely to attain excellent academic 
performance compared to those experiencing the "Low" stress level.

Table 9. Pearson correlation

\begin{tabular}{ll}
\hline Variable & Academic performance \\
\hline Stress level & -0.0650 \\
\hline
\end{tabular}

Table 9 presents the Pearson correlation coefficient. It measures the linear relationship between two variables by looking at the sign and strength of the coefficient. The correlation coefficient between academic performance and stress level was -0.0650. It implies negative and weak linear relationship between the two variables. This is the case because the variables are not linear. Academic performance is binary while stress level is categorical.

Table 10. Effect of the confounding variables on the interaction between academic performance and stress level

\begin{tabular}{|c|c|c|c|c|c|}
\hline Interaction & $\boldsymbol{\beta}$ & $S E \beta$ & t-statistic & P-Value & $95 \% C I$ \\
\hline Constant & .5612 & .2177 & 2.58 & .0100 & {$[.1335, .9889$} \\
\hline Gender & .1154 & .1002 & 1.15 & .2500 & {$[-.0815, \quad .3122]$} \\
\hline \multicolumn{6}{|l|}{ Level of study } \\
\hline Second year & .0885 & .1592 & 0.56 & 0.578 & {$[-.2243, .4013]$} \\
\hline Third year & -.1211 & .1603 & -0.76 & 0.450 & {$[-.4359, .1938$} \\
\hline Fourth year & .1027 & .1882 & 0.55 & 0.585 & {$[-.2669, .4723$} \\
\hline Fifth year & .3181 & .3191 & 1.00 & 0.319 & {$[-.3086, \quad .9448]$} \\
\hline Locus of control & .0013 & .0099 & 0.14 & 0.892 & {$[-.0182, \quad .0209]$} \\
\hline \multicolumn{6}{|l|}{ College } \\
\hline CBPS & $.0309^{*}$ & .1482 & 6.96 & 0.000 & {$[.7398,1.3219$} \\
\hline CEES & $.7385^{*}$ & .1550 & 4.76 & 0.000 & {$[.4339,1.0429]$} \\
\hline CHS & $.3041 * *$ & .1688 & 1.80 & 0.072 & {$[-.0275, \quad .6357]$} \\
\hline $\mathrm{CAE}$ & $.6961^{*}$ & .1453 & 4.79 & 0.000 & {$[.4108, \quad .9815$} \\
\hline CAVs & -.5689 & 1.1875 & -0.48 & 0.632 & {$[-2.9015,1.7635]$} \\
\hline
\end{tabular}

R2.1136; No. of observations: 584.

Note. ${ }^{*}$ and $* *$ mean significant at the $5 \%$ and $10 *$ level of significant respectively.

In Table 10, the influence of gender, level of study, locus of control, and college on the relationship between academic performance and stress level was determined. Some categories of college were found to have statistically significant influence on the interaction between academic performance and stress level. Specifically, the results indicate that students in the "CBPS", "CEES", "CHS", and "CAE" had statistically significant influence on the relationship between academic performance and stress level at the $5 \%$ and $10 \%$ levels of significance $(\mathrm{t}=6.96, \mathrm{p}=0.000),(\mathrm{t}=4.76, \mathrm{p}=0.0000),(\mathrm{t}=1.80, \mathrm{p}=0.072)$, and $(\mathrm{t}=4.79, \mathrm{p}=0.0000)$ 


\section{MInstitute Macrothink $_{\text {Int }}$}

respectively. Gender, level of study, and locus of control had no statistically significant influence on the interaction between academic performance and stress level $(\mathrm{t}=1.15$, $\mathrm{p}=0.2500),(\mathrm{t}=0.56, \mathrm{p}=0.5780),(\mathrm{t}=-0.76, \mathrm{p}=0.4500),(\mathrm{t}=0.55, \mathrm{p}=0.585),(\mathrm{t}=1.00,0.319)$ for level of study, and $(\mathrm{t}=0.14, \mathrm{p}=0.892)$ respectively.

Table 11. Marginal contribution of each confounding variable on the relationship between academic performance and stress

\begin{tabular}{lcclll}
\hline Interaction & \multicolumn{1}{c}{$\boldsymbol{\beta}$} & $\boldsymbol{S E} \boldsymbol{\beta}$ & $\boldsymbol{t}$-statistic & $\boldsymbol{P}$-Value & \multicolumn{1}{c}{$\mathbf{9 5 \%} \boldsymbol{C I}$} \\
\hline Gender & .1154 & .1002 & 1.15 & 0.250 & {$[-.0815, .3122]$} \\
\hline Level of study & & & & & \\
\hline Second year & .0885 & .1592 & 0.56 & 0.578 & {$[-.2243, .4013]$} \\
\hline Third year & -.1211 & .1603 & -0.76 & 0.450 & {$[-.4359, .1938]$} \\
\hline Fourth year & .1027 & .1882 & 0.55 & 0.585 & {$[-.2669, .4723]$} \\
\hline Fifth year & .3181 & .3191 & 1.00 & 0.319 & {$[-.3086, .9448]$} \\
\hline Locus of control & & & & & \\
\hline College & .0013 & .0099 & 0.14 & 0.892 & {$[-.01818, .02087]$} \\
\hline CBPS & $.0309^{*}$ & .1482 & 6.96 & 0.000 & {$[.7398,1.3219]$} \\
\hline CEES & $.7385^{*}$ & .1550 & 4.76 & 0.000 & {$[-4339,1.0429]$} \\
\hline CHS & $.3041^{* *}$ & .1688 & 1.80 & 0.072 & {$[-.0275, .6357]$} \\
\hline CAE & $.6961^{*}$ & .1454 & 4.79 & 0.000 & {$[.4108, .9815]$} \\
\hline CAVs & -.56891 & .1875 & -0.48 & 0.632 & {$[-2.9015,1.7635]$} \\
\hline
\end{tabular}

Note. * and ** mean significant at the $5 \%$ and $10 \%$ level of significance.

Table 11 shows the marginal contributions of each confounding variable on relationship between academic performance and stress level. Regarding gender, the relationship between academic performance and stress level was found to be $11.54 \%$ more for males compared to females. The effect was however, not significant $(\mathrm{t}=1.15, \mathrm{p}=0.250)$. On the level of study, the relationship between stress level and academic performance of students in second, fourth, and fifth years of study were $8.85 \%, 10.27 \%$, and $31.81 \%$ more compared to those in first year. However, the effect was not statistically significant $(\mathrm{t}=0.56, \mathrm{p}=0.578),(\mathrm{t}=0.55, \mathrm{p}=0.585)$, and $(\mathrm{t}=1.00,0.319)$ respectively. The relationship between academic performance and stress level of students in third year was found to be $12.11 \%$ less compared to students in first year. The effect was not statistically significant $(\mathrm{t}=-0.76, \mathrm{p}=0.450)$. Locus of control had the least marginal contribution to the relationship between stress level and academic performance at $0.13 \%$ and it was statistically insignificant $(t=0.14, p=0.892)$.

The relationship between stress level and academic performance of students in the College of Biological and Physical Sciences (CBPS), College of Education and External Studies (CEES), College of Health Sciences (CHS), and College of Architecture and Engineering (CAE) were found to be $3.1 \%, 73.85 \%, 30.41 \%$, and $69.61 \%$ higher compared to that of students in the College of Humanities and Social Sciences (CHSS). The marginal contribution was 
statistically significant at the 5\% level of significance for CBPS, CEES, and CAE $(\mathrm{t}=6.96$, $\mathrm{p}=0.0000), \quad(\mathrm{t}=4.75, \quad p=0.0000)$, and $(\mathrm{t}=4.79, \quad \mathrm{p}=0.0000)$ respectively. The marginal contribution for CHS was statistically significant at the $10 \%$ level of significance $(\mathrm{t}=1.80$, $p=0.072$ ). The relationship between stress level and academic performance of students in the College of Agriculture and Veterinary Sciences (CAVs) was found to be 56.89 less than that of students in CHSS. It was not statistically significant $(\mathrm{t}=-0.48, \mathrm{p}=0.632)$.

\section{Discussion}

The findings of this study showed that stress has a moderate but significant association with academic performance $\left(\chi^{2}=9.49, \mathrm{n}=584, \mathrm{df}=4, p=0.048\right)$. Higher levels of stress resulted in poor academic performance. This finding concurs with similar findings in other studies (Raffidah, Azizah, Norzaid, Salwani, \& Noraini, 2009) but not others which have not confirmed this relationship (Womble, 2003; Awofodu \& Emi, 2011). This finding fits in line with Selye' (1976) proposal that long term exposure to stress may undermine the individual's biological and cognitive abilities to operate. The students' exposure to stressors may create intrinsic experiences such as negative physical and mental health outcomes that could interfere with their academic performance.

The confounding effects of several intrinsic and extrinsic variables were investigated. Stress and academic performance are significantly related within age groups $19-22$ years $\left(\chi^{2}=8.34\right.$, $\mathrm{n}=101, \mathrm{df}=4, p=0.049)$ and 23-26 years $\left(\chi^{2}=9.72, \mathrm{n}=79, \mathrm{df}=4, p=0.041\right)$. The association between stress and academic performance is strong and statistically significant in the two age categories. The results indicate that age mediates the relationship between stress and academic performance. Older students appear to be better at dealing with their problems and consequently minimize the effects of stress on their academic work. According to researchers, people are able to manage stress better as they get older (Monteiro et al, 2014, Hara et al, 2014). The students in this study are not only getting older but also becoming more adept at dealing with issues they face in campus.

Gender variable was of interest in this research because it has been found to influence stress experience (Scott, 2009). Across the gender categories, the relationship between stress and academic performance was found to be statistically significant among both male $\left(\chi^{2}=12.18\right.$, $\mathrm{n}=319, \mathrm{df}=4, p=0.025)$ and female $\left.\chi^{2}=9.74, \mathrm{n}=265, \mathrm{df}=4, p=0.049\right)$ respondents. The results therefore suggest that the relationship between stress and academic performance is significant for both male and female students. This implies that stress will affect academic performance in both male and female students. The findings concur with some studies (Talib \& Zia-ur-Rehman, 2012 but not others (Kania, 2014).

Several studies indicate that stress may be caused by the type of course that students are doing due to the demands of the course (Fairbrother \& Warn, 2003; Byran and Bigel, 2008; Lawrence, Williams \& Eiland, 2009; Britz \& Pappas, 2012). Six categories of courses were used in this study. A three way chi-square analysis was done to test the significance of the influence of type of course on the relationship between stress and academic performance. The results do not support studies that suggest that stress is an issue in science and medical courses only (Harris, Millichamp \& Thomson, 2015). For instance the relationship between 
stress and academic performance was significant among students in Agriculture and Veterinary $\operatorname{Sciences}\left(\chi^{2}=12.46, \quad \mathrm{n}=58, \mathrm{df}=4, \quad p=0.014\right) \quad$ Humanities and Social Sciences $\left(\chi^{2}=10.968, \mathrm{n}=187, \mathrm{df}=4, p=0.046\right)$ only but not others

Some researchers have found that stress experience may depend on the students' level of study (Raffidah, Azizah, Norzaidi, Chong, Salwani \& Noraini, 2009). The extent to which the level of study influences the relationship between stress and academic performance has received limited attention. The researchers addressed this shortcoming in the current study. Though this study covers five years of study, some programs such as Arts and Education are for four years. Others such as Engineering and Veterinary Sciences go for five years. The study looked at whether these courses mediate the relationship between stress and academic performance. Stress and academic performance therefore have moderate but significant association with each other within the first year $\left(\chi^{2}=9.56, \mathrm{n}=80, \mathrm{df}=4, p=0.048\right)$ and fourth year $\left(\chi^{2}=13.44, \mathrm{n}=83, \mathrm{df}=4, p=0.015\right)$ of study only. This is probably because during the first year of study, students may be faced with several challenges associated with adapting to new social and academic environment. As the students move towards the end of their programs a wide range of stressors may set in interfering with the students learning process including fear about the future (Thawabieh \& Qaisy, 2012).

Locus of control has been associated with stress experience (Zotovic, 2004; Sarrasin. Mayor $\&$ Faniko, 2014). The interest in this study is to find out the mediating role of locus of control in the relationship between stress and academic performance. Stress and academic performance has strong and statistically significant association within both internal locus of control $\left(\chi^{2}=21.74, \mathrm{n}=256, \mathrm{df}=4, p=0.001\right)$ and external locus of control $\left(\chi^{2}=10.566\right.$, $\mathrm{n}=328, \mathrm{df}=4, p=0.047)$. In both cases stress has significant effect in academic performance but in different but at different levels of significance. This finding confirms the influence of mediating role of locus of control in the effect of stress on academic performance (Lecic-Tosevski \& Stepanovic, 2011). Locus of Control may empower individuals to handle their crisis (Stewart \& De George-Walker (2014) This implies that students with internal locus of control, unlike their colleagues with external locus of control, were likely to deal with stress more successfully and consequently reduce the effect of stress on academic performance

\section{Conclusions}

This study has identified several causes of stress among University of Nairobi students. Most of the students report experiencing between moderate to high stress levels. A higher proportion of male participants than female participants reported moderate to high levels of stress. The study revealed that stress was related to academic performance. The relationship between stress and academic performance was confounded by gender and locus of control. However this relationship was confounded by only certain categories of age, level and course of study. The university should institute programs that can help identify and reduce causes and effects of stress. The counseling programs of the university should be strengthened. Finally further research should be undertaken to investigate the coping strategies employed by the students. 


\section{References}

Alzahem, A. M., Van der Mollen, H. T., \& De Boer, B. J. (2013). Effect of Year of Study on Stress Levels in Male Undergraduate Dental Students. Advances in Medical Education and Practice, 2013(4), 217-222. https://doi.org/10.2147/AMEP.S46214

Arnett, J. J. (2000). Emerging Adulthood: A theory of development from the late teens through the twenties American Psychologist, 55, 469-480. https://doi.org/10.1037/0003-066X.55.5.469

Awofode A. D., \& Emi, I. J. (2011). An Investigation Into The Relationship Between Stress and Academic Achievement Of Biology Students in Nigerian Universities .A Case Study Of Solarin University Of Education Jagun, Ijebu-ode ogun state. Science Journal of Psychology, 2011, 1-12.

Banu, P., Deb, S., Vardhan, V., \& Rao, T. (2015). Perceived Academic Stress of University Students across Gender, Academic Streams, Semesters, and Academic Performance. Indian Journal of Health and Well-being, 6(3), 412-416

Bayram, N., \& Bilgel, N. (2008). The prevalence and socio-demographic correlations of depression, anxiety and stress among a group of university students. Social Psychiatry and Psychiatric Epidemiology, 43(8), 667-672. https://doi.org/10.1007/s00127-008-0345-x

Bressler, L.A., \& Bressler, M. E. (2007). The Relationship Between Self- esteem and Selfefficacy among Distance Learning Students in Accounting Information Systems Online Classes. International Journal of innovation and learning, 4(3), 274-289. https://doi.org/10.1504/IJIL.2007.012382

Britz, J., \& Pappas, E. (2012). Sources and Outlets of Stress among University Students. Correlations between Stress and Unhealthy Habits. Undergraduate Research Journal for the Human Sciences, 9, 1-11. Retrieved from: http://www.kon.org/urc/v9/britz.html.

Chen, H., Wong, N., Ran, M., \& Gilson, C. (2009). Stress among Shanghai University Students: The Need For Social Work Support. Journal of Social Work, 9(3), 323-344. https://doi.org/10.1177/1468017309334845

Daughters, S. B., Gorka, S. M., Matuslewicz, A., \& Anderson, K. (2013). Gender-specific Effect of Psychological Stress and Cortisol Reactivity on Adolescent Risk-taking. Journal of Abnormal Child Psychology, 41(5), 749-758. https://doi.org/10.1007/s10802-013-9713-4

Eisenberg, D., Hunt, J., \& Spear, N. (2013). Mental Health in American Colleges and Universities: Variation across Student Subgroups and Across Campuses. Journal of Nervous and Mental Diseases, 201(1), 60-67. https://doi.org/10.1097/NMD.0b013e31827ab077

Ezeh, O. H., Ezeh, C. C., \& Okey, B. I. (2016). Prevalence, Sources, and Patterns of Stress among University Students. African Journal for the Psychological Studies of Social Issues, $19(1), 16-36$.

Fairbrother, K., \& Warn, J. (2003). Workplace Dimensions, Stress and Job Satisfaction. 
Journal of Managerial Psychology, 18(1), 8-21. https://doi.org/10.1108/02683940310459565

Frank, A. N., \& Karyn, D. J. (2005). Introduction to Professional Counseling. Boston: Pearson Education Inc.

Gade, S., Chan, S., \& Gupta, M. (2014). Perceived Stress among Medical Students : To Identify its Sources and Coping Strategies. Medical Education, 2(1), 80-86. https://doi.org/10.4103/2321-4848.133845

Gokul, G., \& Jayalakshmi, S. (2016). Mental Stress Levels of Students Studying in Different Professional Courses. Journal of Pharmaceutical Sciences and Research, 8(6), 483-486.

Gudo, C. O., Olel, M. A., \& Oanda, I. O. (2011). University Expansion in Kenya and Issues of Quality Education Challenges and Opportunities. International Journal of Business and Social Sciences, 2(10), 203-214.

Hara, Y., Hisatami, M., \& Ito, H. (2014). Effects of Gender, Age, Family Support, and Coping of Patients with Type 2 AIabetes Mellitus Biopsychosocial Medicine, 8(16). https://doi.org/10.1186/1751-0759-8-16

Harris, R. C., Millichamp C. J., \& Thomson, W. M. (2015). Stress and Coping in $4^{\text {th }}$ year Medical and Dental Students. New Zealand Dental Journal, 111(3), 102-107. PMID:26502598

Heiman, T. (2004). Examination of the salutogenic model, support resources, coping style, and stressors among Israeli university students. The Journal of Psychology, 138(6), 505-520. https://doi.org/10.3200/JRLP.138.6.505-520

Ibrahim, A., Kelly, S. J., Adams, C. E., \& Glazebrook, C. (2013). A Systematic Review of Studies of Depression Prevalence in University Students. Journal of Psychiatric Research, 47(3), 391-400. https://doi.org/10.1016/j.jpsychires.2012.11.015

Jacob, T., \& Einstein, O. (2016). Stress among Bachelor of Physical Therapy Students in Israel during Clinical Practice and its Assoiation with Academic Achievements-Results of a Lngitudinal Study. The Internet Journal of Allied Health Sciences and Practice, 14(1), 1-9.

Jan, L. K., \& Popescu, L. (2014). Israel's Nursing Students' Stress Sources and Coping Strategies during their First Clinical Experience in Hospital Wards- A Qualitative Research. Revista de Asistenta Sociala, 4, 163-188.

Kagan J., \& Baird, A. (2004). Brain and Behavioral Development during Childhood. In M. S. Gazzaniga (Ed.), The Cognitive Neuroscience, 93-104. Cambridge. Massachusetts, MA; MIT Press.

Kania, S. (2014). The Relationship between Gender Differences and Stress. The Huron University College Journal of Learning and Motivation, 52(1), 92-101. Retieved from http://ir.lib.uwo.ca/hucjlm/vol52/iss1/7

Karam, E., Kypri, K., \& Salamoune, M. (2007). Alcohol use among College Students: A International Perspective. Current Opinion Psychiatry, 20(3), 213-221. 
https://doi.org/10.1097/YCO.0b013e3280fa836c

Khan, A. H., Salem, M., \& Shahid, R. (2012). Buffering Role Of Locus Of Control On Stress Among The College / University Teachers Of Bahawalpur. Pakistan Journal of Commerce $\begin{array}{llll}\text { and Social } & \text { Sciences, } & \text { 6(1), }\end{array}$ oai:doaj.org/article:5844094d1f2d42e7974de12072aaf595

Lawrence, B., Williams, C., \& Eiland, D. (2009). Depressive symptoms, stress, and social support among dental students at a historically black college and university. Journal of American College Health, 58(1), 56-63. https://doi.org/10.3200/JACH.58.1.56-63

Lazarus. R. S., \& Folkman, S. (1984). Stress Appraisal and Coping. New York: Springer.

Lecic-Tosevski, D., Vulkovic, O., \& Stepanovic, J. (2011). Stress and Personality, Psychiatriki, 22(4), 290-295. PMID: 22271841.

Lim, H., \& Montalto. (2014). Factors Related to Financial Stress among College Students. Journal of Financial Therapy, 5(1), 19-39. https://doi.org/10.4148/1944-9771.1063

Marcucci, P., Johnstone, D. B., \& Ngolovoi, M. (2008). Higher Educational Cost-Sharing, Dual-Track Tuition Fees, and Higher Educational Access: The East African Experience. Peadboy Journal of Education, 83(1), 101-116. https://doi.org/10.1080/01619560701649232

Melgosa, J. (2004). Less Stress. Madrid: Editorial Safelix, S. L.

Monteiro, N. M., Balogun, S. K., \& Oratile, K. N. (2014). Managing Stress: The Influence of Gender, Age and Emotion Regulation on Coping among University Students in Botswana. International Journal of Adolescence and Youth, 19(2), 153-173. https://doi.org/10.1080/02673843.2014.908784

Munene, I. (January 11, 2016). How the Rise of Ethnic Tension in Kenyan Universities is Hurting the Academy. The Conversation. Retrieved from $\mathrm{http}$ //theconversation.com/how-the-rise-in-ethnic-tensions-at-kenyas-universities-is-hurting-t he-academy-50730.

Nakalema, G., \& Ssenyonga, J. (2013). Academic Stress: Its Causes and Results at a Ugandan University. African Journal of Teacher Education, 3(3). https://doi.org/10.21083/ajote.v3i3.2762

Ndegwa, S., Munene, A., \& Oladipo, R. (2017). Factors Associated with Alcohol Abuse among University Students in a Kenyan University. African Journal of Clinical Psychology, 1, 102-117.

Nganga, G. (2016). Spike in University Enrolment brings New Challenge. University World News: The Global Window on Higher Education. Issue No 413. Retrieved from http://www.universityworldnews.com/article.php?story=20160509141752529

Ngolovoi, M. (2008). Financing higher education in Kenya. Student Perceptions and experiences. Tertiary Education and Management, 14(2), 141-150. https://doi.org/10.1080/13583880802053085 
Njare, M. H. (2013). Factors Associated with Alcohol Abuse among University of Nairobi Students. Unpublished Master of Public Health (MPH) Thesis, University of Nairobi.

Njoroge, M. M., Wangari, T., \& Gichure, C. (2016). Examination Repeats, Semester Deferments and Dropping out as Contributors of Attrition Rates in Private Universities in Nairobi County. International Journal of Education Research, 4(3), 225-240.

Posner, M.I., \& Rothbart, M. K. ( 2017). Integrating Brain Cognition and Culture. Journal of Cultural Cognitive Science, 1(1), 3-15. https://doi.org/10.1007/s41809-017-0001-7

Raffidah, K., Azizah, A., Norzaidi, M. D., Chong, S. C., Salwani, M. I., \& Noraini, I. (2009). The Impact of Perceived Stress and Stress Factors on Academic Performance of Pre-Diploma Science Students. A Malaysia Study. International Journal of Science Research in Education, $2(1), 13-26$.

Rotter, J. B. (1990). Internal vs External Control of Reinforcement: A Case History of a Variable. American Psychologist, 489-493. https://doi.org/10.1037/0003-066X.45.4.489

Sagone, E., \& De Caroli, M. E. (2014). Locus of Control and Academic Self-Efficacy in University Students: The Effects of Self-Concepts. Procedia-Social and Behavioral Sciences, 114(21), 222-228. https://doi.org/10.1016/j.sbspro.2013.12.689

Sarrasin, O., Mayor, E., \& Faniko, K. (2014). Gender Traits and Cognitive Appraisal in Young Adults: The Mediating Role of Locus of Control. Sex Roles, 70(3-4), 122-133. https://doi.org/10.1007/s11199-013-0336-6

Scott, E. (2009). Stress and Women's Health. Medical Review, 4, 23-30.

Selye, H. (1956). Stress of Life. New York: McGraw-Hill.

Selye, H. (1976). Stress in Health and Disease. Reading: MA, Butterworth.

Shepherd, H. (2014). Culture and Cognition: A Process Account of Culture. Sociological Forum, 29(4), 1007-1011. https://doi.org/10.1111/socf.12134

Smith, T., \& Renk, K. (2007). Predictors of academic related stress in college students: An examination of coping social support, parenting and anxiety. NASPA Journal, 44(3), 405-43. https://doi.org/10.2202/1949-6605.1829

Stewart, M. A., \& De George-Walker, L. (2014). Self-handicapping, Performance, Locus of Control and Self- Efficacy: A Path Model. Personality and Individual Differences, 66, 160-164. https://doi.org/10.1016/j.paid.2014.03.038

Talib, N., \& Zia-ur-Rehman, M. (2012). Academic Performance and Perceived Stress among University Students. Educational Research and Review, 7(5), 127-132.

Thawabieh, A. M., \& Qaisy, L. M. (2012). Assessing of Stress among University Students American International Journal of Contemporary Research, 2(2), 110-116.

Thompson, B., Kirby, S., \& Smith, K. (2016). Culture Shapes the Evolution of Cognition. 


\section{Macrothink}

International Journal of Learning and Development

ISSN 2164-4063 2018, Vol. 8, No. 4

Proceedings of the National Academy of Sciences of the United States of America, 113(16), 4530-4535. https://doi.org/10.1073/pnas. 1523631113

Tse, E. C. (2011). A Comparative Analysis of Alcohol Consumption Patterns among Global University Students, 1-11. International CRHRIE Conference. Massachussetts: Scholar Works@UMass Amherst.

Turner, T., Bartlett, D., Andiappan, M., \& Cabot, L. (2015). Students' Perceived Stress and Perception of Barriers to Effective Study: Impact on Academic Performance in Examinations. British Dental Journal, 219(9), 453-458. https://doi.org/10.1038/sj.bdj.2015.850

Wanyoike, B. W. (2015). Suicide Among University Students in Kenya: Causes, Implications and Interventions. Journal of Language Technology and Entrepreneurship in Africa, 6(1), $35-53$

Womble, L. P. (2003). Impact of Stress Factors on College Students, Academic Performance. Retrieved from: http://www.psych.uncc.edu/womble.pdf

Ying, M. L., Shu, C., Ming, Y. W., \& Farn, S. C. (2009). What causes Academic Stress suffered by Students at Universities and Colleges of Technology? World Transactions on Engineering and Technology Education, 7(1), 77-81.

Zotovic, M (2004). Coping with Stress: Basic Conceptual and Theoretical Questions from Standpoint of Transactional Theory. Psihologija, 37(1), 5-32. https://doi.org/10.2298/PSI0401005Z

\section{Copyright Disclaimer}

Copyright for this article is retained by the author(s), with first publication rights granted to the journal.

This is an open-access article distributed under the terms and conditions of the Creative Commons Attribution license (http://creativecommons.org/licenses/by/4.0/). 